\title{
The Dual Nature of Trade: Measuring its Impact on Imitation and Growth*
}

\author{
Michelle Connolly \\ Duke University \\ email: connolly@econ.duke.edu
}

May 1998

\begin{abstract}
:
Imports of goods that embody foreign technology raise a country's output directly as inputs into production and indirectly through reverse-engineering of these goods, which contributes to domestic imitation and innovation. This paper first quantifies spillovers from high technology imports from developed countries to domestic imitation and innovation in both developed and developing countries. It then considers the contribution of foreign and domestic innovation to real per capita GDP growth.

International patent data for 40 countries from 1970 to 1985 are used to create proxies for imitation and innovation. High technology imports, as well as quality-adjusted research and the size of the economy, positively affect both domestic imitation and innovation. Transportation and communication infrastructure positively affects imitation, but does not appear to play a role in innovation. Interestingly, foreign direct investment, often considered an important mechanism for technological diffusion to developing nations, does not significantly affect either domestic innovation or imitation. Finally, while both foreign and domestic innovation contribute positively to real per capita GDP growth, foreign technology from developed countries appears to play a far greater role in growth than domestic technology.

Key Words: Embodied Technology, Technological Diffusion, Learning-to-Learn, Imitation, Innovation, North-South Trade, Endogenous Growth, Convergence

JEL: F1, F43, O30, O31, O34, O40, O14

*This paper was previously titled "Technology, Trade and Growth: Empirical Findings." I thank Robert Evenson, Amy Glass, James Harrigan, Ann Harrison, William Hutchinson, Mitch Kaneda, Wolfgang Keller, Jean Lanjouw, Edward Leamer, David Prentice, Xavier Sala-i-Martin, Francesca Sanna-Randaccio, Matthew Slaughter, T.N. Srinivasan, and Kei-Mu Yi for helpful comments and suggestions. Joe Davis and Diego Valderrama provided valuable research assistance. I remain responsible for any errors. Financial support from a Duke University Arts and Sciences Research Grant is gratefully acknowledged.
\end{abstract}




\section{Introduction}

Imports of goods that embody foreign technology can raise a country's output in two ways. Firstly, use of more advanced foreign technology directly increases domestic output. Secondly, reverse engineering of these goods should positively affect domestic imitation and innovation. This paper first attempts to quantify spillovers from imports of high technology goods from developed countries to domestic imitation and innovation in both developed and developing countries. In turn, the paper considers the importance of foreign and domestic innovation to real per capita GDP growth.

Imitative activity, by its very nature, is difficult to measure. Hence, this is one of the first studies that attempts to quantify both imitative and innovative activity across developed countries (DCs) and less developed countries (LDCs). ${ }^{1}$ Additionally, in assessing the importance of trade to the international diffusion of technology, this paper looks at imports within certain specific Standard International Trade Classification (SITC) classes so as to separate out the effects of imports of goods that embody technology, from general openness effects. Previous empirical studies on trade and technological diffusion have focused on general imports as the channel for technological diffusion (Eaton and Kortum 1996a and 1996b; Coe and Helpman 1995; Coe, Helpman, and Hoffmaister 1997; Keller 1997; Wang and $\mathrm{Xu} \mathrm{19972}$ ). Relative to much of the existing literature, this paper distinguishes a) between high-technology imports and general imports and b) between imitative and innovative activity. Further, this paper includes both LDCs and DCs, allowing consideration of how technological diffusion from a DC to an LDC might differ from diffusion across DCs.

The paper is organized as follows. Section II presents a brief overview of the endogenous growth model put forth in Connolly (1997) which guides the empirical analysis. The model postulates that trade in intermediate capital goods and the quality of transportation and communication infrastructure play significant roles in the international

\footnotetext{
${ }^{1}$ Through surveys, Mansfield, Swartz, and Wagner (1981) quantify the cost (on average 65\% of the cost of innovation) and speed (on average 70\% of time required for innovation) of imitation for 48 product innovations within the U.S. chemical, drug, electronics, and machinery industries. Still their study does not quantify imitative activity across countries or over time.
} 
diffusion of technology. The model is loosely used to empirically consider first the role of trade in the processes of imitation and innovation, and second the effect these processes have on growth. Section III describes the data and defines the innovation and imitation proxies. Section IV presents the empirical results and section V concludes.

\section{Theoretical Considerations}

For brevity, I present only the more salient features of the model of technological diffusion through trade and imitation developed in Connolly (1997). The model is a quality-ladder model with North-South trade, which incorporates the concept of learningto-learn in both innovative and imitative processes. ${ }^{3}$ The idea of learning-to-learn is that research allows firms to gain insights not only into the particular activity they are engaged in at the time, but also into the process of research itself. As a firm successfully imitates higher and higher quality levels of a particular type of good, it will gain insight into how goods are engineered and improved upon. So imitation not only makes the firm better at future imitation, but also improves the firm's chances of successfully inventing the next quality level on its own. ${ }^{4}$ Hence, learning-to-learn differs from learning-by-doing in that the skills gained are general and thus applicable to different types of research, rather than being limited to the exact task in which the learning occurs.

Domestic technological progress occurs via innovation or imitation, while growth is driven by technological advances in the quality of domestically available inputs, regardless of country of origin. Hence aggregate final goods production in each country is:

$$
Y=A L^{\alpha} \sum_{j=1}^{J}\left[q^{k_{j}}\left(x_{k_{j}}+x_{k_{j}}^{*}\right)\right]^{1-\alpha}, \quad \text { where } 0<\alpha<1 .
$$

$A$ is a productivity parameter dependent upon the country's institutions, such as tax laws, property rights, and government services, and $L$ is the labor input used by the representative firm for final goods production. Following conventional notation for rising

\footnotetext{
2 Wang and Xie (1997) consider research and development (R\&D) spillovers through capital goods trade and foreign direct investment (FDI) but consider only industrialized countries.

${ }^{3}$ Following convention, the North is considered a DC and the South a LDC.
} 
product quality models (Grossman and Helpman 1991a and 1991b; Aghion and Howitt 1992; Barro and Sala-i-Martin 1995 and 1997), there are a fixed number, $J$, of intermediate goods, whose quality levels are improved upon through innovation (or imitation). $q$ reflects the size of quality improvements with each innovation, while $k$ reflects the rung at which the good is located on a quality ladder. Normalizing so all goods begin at quality level 1 , the quality level of an intermediate good in sector $j$ will rise from 1 to $q$ with the first innovation, to $q^{2}$ with the second innovation, and to $q^{k_{j}}$ with the $k_{j}$ th innovation. Thus, $q^{k_{j}}\left(x_{k_{j}}+x_{k_{j}}^{*}\right)$ is the quality-adjusted amount of the intermediate good of type $j$ (with the asterisk denoting imports) used in final goods production.

Within each intermediate goods sector, limit pricing (along with a constant marginal cost of production across domestic firms) allows the Northern firm with the leading technology to capture the world market. However, a Southern firm can take the world market from the lead firm by imitating the lead Northern good, since it is able to underprice the Northern firm because of lower marginal costs of production. ${ }^{5}$ Firms in both countries decide how many resources to devote to innovative or imitative research based on expected present value of profits for successful research, which depends on the probabilities of innovation and imitation.

For an intermediate goods sector presently at quality level $k, p_{k}$, is the probability per unit of time of successful innovative or imitative research. Specifically, $p_{k}$ follows a Poisson process which depends positively on resources devoted to research, $z_{k}$, and past learning-to-learn, $\vartheta_{k}$, within that domestic industry, and negatively on the complexity, $\phi(k)$, of the good upon which firms are attempting to improve/imitate:

$$
\begin{aligned}
& p_{k}=z_{k} \phi(k) \vartheta_{k}, \quad \text { where } \\
& \vartheta_{k}=\max \left(\beta_{C} q_{C}^{k_{j}}, \beta_{I} q_{I}^{k_{j}}\right), \quad \quad \beta_{I}>\beta_{C}>0 .
\end{aligned}
$$

\footnotetext{
${ }^{4}$ This is much like graduate studies, where the first years in graduate school are spent reverse-engineering the pre-existing stock of academic knowledge. During that time, students attain the skills and detailed understanding of the subject matter necessary to hopefully "innovate" on their own.

${ }^{5}$ Hence, there is a Vernon-type product cycle.
} 
Subscripts $C$ and $I$ denote copying (imitation) and innovation, respectively. $\vartheta_{k_{j}}$ reflects the positive spillover effects of past learning-to-learn through imitation or innovation. For a particular domestic intermediate goods sector, $q_{C}^{k_{j}}$ is the highest quality level attained through imitation and $q_{I}^{k_{j}}$ is the highest quality level attained through innovation. If a domestic industry has no imitative experience $q_{C}^{k_{j}}=0$, and if it has no innovative experience $q_{I}^{k_{j}}=0 .{ }^{6} \beta_{C}$ and $\beta_{I}$ are positive coefficients on past imitative and innovative experience, respectively. $\beta_{I}>\beta_{C}$ since there should be greater learning-to-learn effects in innovation than in imitation. Finally, $\phi\left(k_{j}\right)$ reflects the increased difficulty of innovation/imitation of higher quality goods, implying a lower probability of success, all else equal. This term differs for innovative and imitative processes. For innovative research the difficulty term includes a country specific fixed cost of innovation, $\zeta_{I}$, as well as a measure of the quality level upon which the firms is attempting to improve:

$$
\phi_{I}(k)=\left(1 / \zeta_{I}\right) q^{-k / \alpha} .
$$

For imitative research this terms further includes an interaction term, $\omega$, reflecting lower costs of imitation when firms are exposed to higher levels of capital good imports from the DC, as well as higher transportation and communication infrastructure quality. The difficulty of imitation term also depends on the ratio, $\hat{q}$, of the technology levels between the imitating and innovating country (denoted with subscripts $S$ and $N$ respectively):

$$
\phi_{C}\left(k_{j}-1\right)=\frac{1}{\zeta_{C} \hat{q}_{j}^{\sigma}\left(e^{-\omega}+1\right)} q^{l-\left(k_{j} / \alpha\right)}, \sigma>0 \text {, and } \hat{q}_{j}=\frac{q^{k_{S j}}}{q^{k_{N j}}} .
$$

Thus $\hat{q}$ reflects diminishing returns to imitation as the pool of goods that can be targeted for imitation decreases.

Given this setup, and assuming balanced trade where all Southern intermediate goods sectors are undertaking imitative research, equilibrium rates of innovation and imitation are as follows:

\footnotetext{
${ }^{6} \mathrm{I}$ assume that each sector has experience in at least one type of research. If not, then $\theta=1$.
} 


$$
\begin{aligned}
& p_{I N}=\left[\frac{\beta_{C}}{\zeta_{C S}\left(e^{-\omega}+1\right)} \Omega_{S}\left(M C_{N}-M C_{S}\right)\right]-r_{S}, \\
& p_{C S}=\frac{\frac{\beta_{I}}{\zeta_{I N}}\left(M C_{S}-\frac{M C_{N}}{q}\right) \Omega_{N}-\frac{\beta_{C}}{\zeta_{C S}\left(e^{-\omega}+1\right)}\left(M C_{N}-M C_{S}\right) \Omega_{S}}{1+r-\frac{\beta_{C}}{\zeta_{C S}\left(e^{-\omega}+1\right)}\left(M C_{N}-M C_{S}\right) \Omega_{S}}, \quad \text { where } \\
& \Omega_{\mathrm{N}}=\left[L_{N} A_{N}^{l / \alpha}\left(\frac{M C_{N}}{M C_{S}}\right)^{l / \alpha}+L_{S} A_{S}^{l / \alpha}\right](1-\alpha)^{l / \alpha}, \\
& \Omega_{S}=\left[L_{N} A_{N}^{l / \alpha}+L_{S} A_{S}^{l / \alpha}\left(\frac{M C_{S}}{M C_{N}}\right)^{l / \alpha}\right](1-\alpha)^{l / \alpha}, \quad \text { and } M C_{N}=1 .
\end{aligned}
$$

Both countries grow at the same rate, driven by Northern technological progress:

$$
\gamma^{*}=\left[\frac{\beta_{C}}{\zeta_{C S}\left(e^{-\omega}+1\right)} \Omega_{S}\left(M C_{N}-M C_{S}\right)-\rho\right] /\left(\frac{1}{q^{(1-\alpha) / \alpha}-1}+\theta\right)
$$

Based strictly on the model, imitation in a given country is a positive function of expenditures on research, real imports of capital goods from DCs, the country's transportation and communication infrastructure level, and past experience in imitative and innovative processes. In addition, factors affecting the profitability of imitation, such as the size of the market, also contribute positively to imitative activities. ${ }^{7}$

Two additional issues, human capital and foreign direct investment (FDI), are not considered in the model, but are relevant to the question of technological diffusion. Specifically, the human capital level of researchers should contribute positively to imitation. This concept is similar to a model by Nelson and Phelps (1966) where the rate of increase in the application of theoretical technology is an increasing function of educational attainment and the gap between the applied and the theoretical level of technology. The only difference is that I consider imitation of foreign technology rather than domestic application of theoretical technology. Further, it is often argued that inflows of FDI can potentially help disseminate technology to the host country.

\footnotetext{
${ }^{7}$ The size of the world market is the relevant measure if a firm is imitating to sell on the world market and there are relatively low transportation costs. However, if a firm plans to only sell domestically, then the size of their domestic market is the relevant measure.
} 
Hence, I estimate the following equation

$$
C_{i t}=\beta_{0}+\beta_{1} R_{i t}+\beta_{2} F_{i t}+\beta_{3} H_{i t}+\beta_{4} N H_{i t}+\beta_{5} P O P_{i t}+\beta_{6} I P R_{i t}+\beta_{7} F D I_{i t}+\mu_{i t},
$$

where $\mu_{i t}=\alpha_{i}+\varepsilon_{i t}$. The variables are named as follows. $C_{i}$ is the imitation proxy, and $R_{i}$ is quality-adjusted research per capita. $F_{i}$ is the per capita measure of the transportation and communication infrastructure level. $H_{i}$ represents imports of high technology goods from DCs as a share of GDP, while $N H_{i}$ represents imports of all goods other than high technology goods from DCs also as a share of GDP. Non-high technology imports are included, to determine whether imports in general, versus technology embodied in imports, matter to imitation. If this variable is positive and statistically significant, while the high technology imports variable is not, this would imply that it is simply an openness effect, rather than the technology embodied in high technology imports in particular, which matters to imitation. $I P R_{i t}$ is the Park and Ginarte (1997) intellectual property rights (IPRs) protection index for country $i$, and $F D I_{i t}$ measures inflows of foreign direct investment into country $i$ as a share of GDP. All variables used in these regressions are in natural logarithms with the exception of FDI inflows since these at times take on negative values. $\alpha_{i}$ represents a latent individual effect which is assumed to be time-invariant and identically distributed across individual countries with variance $\sigma_{\alpha}^{2}$. The $\varepsilon_{i}$ are assumed to be identically, independently distributed with zero mean and constant variance, $\sigma_{\varepsilon}^{2}$, conditional on the explanatory variables.

The imitation proxy, $C_{i}$, is not scaled since it represents increased technology or knowledge available in the economy after imitation: i.e. technology is a non-rival good freely available domestically. Hence, a per capita version of this proxy would not be appropriate. Further, since expected profits for imitative research depend on the size of the market in which the imitated good will be sold, domestic population, $P O P_{i t}$, is included to capture possible scale effects. ${ }^{8}$

\footnotetext{
8 Theory also suggests that the scale of high technology imports affects research. There are two reasons to argue that high technology import levels matter. First, suppose that each person who is exposed to a new good has a given probability that they will copy it. For a country as a whole, a good need only be copied by one domestic resident for the technology embodied in it to be acquired domestically. Hence, the number of individuals exposed to the new good matters, implying the greater the volume of imports of a
} 
Similarly to imitation, innovation should depend positively on quality-adjusted research. Further, high technology imports and the transportation and communication infrastructure level positively affect equilibrium rates of innovation. Intuitively, high technology imports, the infrastructure level, and possibly FDI inflows increase knowledge of foreign innovations, thereby positively affecting domestic innovation (perhaps through initial imitation). Hence, I consider an innovation regression similar to that for imitation:

$$
\begin{aligned}
& I_{i t}=\beta_{0}+\beta_{l} R_{i t}+\beta_{2} F_{i t}+\beta_{3} H_{i t}+\beta_{4} N H_{i t}+\beta_{5} P O P_{i t}+\beta_{6} I P R_{i t}+\beta_{7} F D I_{i t}+\mu_{i t}, \\
& \mu_{i t}=\alpha_{i}+\varepsilon_{i t},
\end{aligned}
$$

where $I_{i t}$ is the innovation rate in country $i$ and all other variables are defined as before.

Growth in output per worker is a positive function of growth in both the aggregate quality level and the intermediate goods stock. If a country allows free trade in intermediate goods then the quality level of intermediate goods is determined by the technology of lead innovators, whether domestic or foreign. If the country is cut off from trade, then the quality level is determined by domestic research, either in imitation or innovation, depending on their relative costs. I therefore consider foreign innovation, as well as domestic innovation and imitation, in the GDP growth regressions.

Average annual data for three subperiods, 1970-74, 1975-79, and 1980-84 are used in the analysis that follows. For each subperiod, growth of real per capita GDP, $Y_{i}$, (in ln differences) is a function of growth in the per capita physical capital stock, $K_{i}$, the innovation rate, $I_{i}$, the imitation rate, $C_{i}$, and growth of real imports of high technology goods per capita, $H_{i} . H_{i}$ proxies for the direct effect of foreign technology embodied in imported inputs used in domestic production. Finally, the 1969 real per capita GDP level, $Y_{i, t_{-}}$, is included as an independent variable, to test for conditional convergence:

$$
\gamma_{Y_{i t}}=\beta_{0}+\beta_{1} Y_{i, t_{-} l}+\beta_{2} \gamma_{K_{i t}}+\beta_{3} I_{i t}+\beta_{4} C_{i t}+\beta_{5} \gamma_{H_{i t}}+\mu_{i t}, \quad \mu_{i t}=\alpha_{i}+\varepsilon_{i t}
$$

particular good, the greater the likelihood it will be imitated. Second, for importing firms, the greater the volume of imported goods they distribute and service, the lower their costs of imitation, making them more likely to imitate the good, all else equal. Regressions using high technology import levels, rather than their share in GDP, and GDP as a scale variable rather than population, yield results that are generally consistent with the results reported here. 


\section{Data}

Since I am particularly interested in the diffusion of technology from developed to less developed nations, all countries for which data are available are included. There are limited data for 73 countries. However, only a subset of these countries is included in each regression depending upon which countries have the necessary data. ${ }^{9}$ This paper therefore provides empirical analysis inclusive of some developing countries not often considered in empirical papers on technological diffusion.

As Eaton and Kortum (1996b) point out, many studies on technological progress consider total factor productivity, which attempts to measure the benefits of innovation, while others consider R\&D expenditures, which reflect inputs into the process of innovation. Finally, studies that consider patents provide a measure of output from the $\mathrm{R} \& \mathrm{D}$ process.

Following this notion, this paper relies on patent data to reflect a positive fraction of successful outcomes in research. Specifically, the proxy for the rate of innovation is defined as U.S. patents granted to residents of a given country each year (by date of application) as reported by the U.S. Patent and Trademark Office. This assumes that if an innovation is truly novel, its inventor will apply for and be granted a U.S. patent. There are of course many reasons why an inventor of a truly novel product or process might not apply for a patent in the United States. If the inventor has no plans to sell in the U.S. and is not worried about having American firms copy their good, they will not bother applying for a U.S. patent. Furthermore, there are industries in which it is easy to invent around a patent. Within these industries, firms will generally avoid applying for patents since this might divulge information that increases the chances of losing their market to a competitor. For these reasons, this proxy generally underestimates innovative activity.

The imitation proxy is defined as the number of applications for domestic patents by home residents (as reported by the World Intellectual Property Organization (WIPO) in annual issues) minus U.S. patent applications by residents of that same country. The

\footnotetext{
${ }^{9}$ Innovation regressions include up to twenty, mostly developed countries, imitation regressions include up to thirty countries, and growth regressions include forty countries.
} 
situation hopefully captured by this proxy is one where a firm has imitated say an American invention, but believes it will be able to get a patent in its home country. This could either be because of more lax novelty requirements at home, or simply because the American firm has not patented its invention in that particular country. However, the imitating firm would not apply for a patent in the U.S. since the novelty requirements are more stringent and the U.S. firm will have patented in the U.S. This assumes that non-U.S. residents will attempt to patent imitative goods in their home countries, but will only seek a U.S. patent if they consider their goods to be truly novel.

There are several drawbacks to this proxy for imitation. As previously discussed, there may be economic reasons for which a firm with a new invention may try to patent in their home country but not in the U.S. For example, a firm may invent a good that is particularly tailored to the domestic demand of its home country, but might not be in demand in the U.S. The firm would therefore seek a domestic patent but would not apply for a U.S. patent. This type of situation will cause the imitation proxy to overestimate imitative activity. On the other hand, the proxy also depends on enforcement of patent laws in the home country and in the U.S. For example, if patents are not enforced in a given country, then imitative activity might be taking place, but no firms would bother seeking domestic patent protection. Similarly, if a country has strict novelty requirements, imitators would not be granted a domestic patent. Hence, for those types of countries, this measure underestimates the true quantity of imitation taking place. Overall, this proxy will underestimate imitative activity in LDCs. With these caveats in mind, I use this proxy as a first attempt to quantify imitative activity. ${ }^{10}$

One final consideration when using domestic patent data is that the Japanese patent system leads to far higher domestic patent counts than other countries (for the same amount of innovative activity). ${ }^{11}$ This makes Japan artificially appear to imitate far more

\footnotetext{
${ }^{10}$ Litigation might provide an alternative measure of IPR infringement. However, a majority of the IPR infringement cases are settled out of court, often prior to official filing. Hence, only a small fraction of imitative activity would be reflected by the small number of cases that actually are filed in courts of law.

${ }^{11}$ Eaton and Kortum (1994) translate 4.9 Japanese domestic patent applications as being equivalent to 1 application elsewhere. This number is based on a study by Okada (1992), which finds that Japanese patents granted to foreigners on average contained 4.9 times more inventive claims as Japanese patents granted to domestic residents.
} 
than other countries since domestic patent applications enter positively in the imitation proxy. Since this peculiarity of the Japanese patent system makes Japan an outlier in the sample, a dummy variable is used for Japan in the imitation regressions. The dummy is not used in the innovation regressions since the innovation proxy is based on U.S. patents and hence is not influenced by Japan's patenting system.

For brevity the remainder of the data series are described in the appendix.

\section{Empirical Results}

The empirical analysis which follows uses panel data consisting of three five year periods, 1970-74, 1975-79 and 1980-84, for a cross-section of up to 40 countries. All variables (other than $F D I$ ) are in natural logarithms and are expressed in real terms. Instrumental Variable Estimation is used throughout. A series of estimation techniques are undertaken. First a straight forward pooled $2 S L S$ regression is considered for illustrative purposes since this would be the equivalent to a pooled $O L S$ regression were there no endogeneity problems. Then cross-section, fixed effects $(F E)$, and random effects $(R E)$ regressions are completed, although only the cross-section and $R E$ regressions are presented. ${ }^{12}$ It should also be noted that there is evidence of multicollinearity problems in the regressions that follow. The regressions nonetheless yield robust results.

\section{Imitation and Innovation}

\footnotetext{
12 Random effects estimation is $B L U E$ if there is no correlation between the latent individual effect and the explanatory variables. If such correlation exists, then fixed effects estimation, which considers deviation from time averages, is the most appropriate estimation technique since its estimates are consistent and unbiased regardless of such correlation. Unfortunately, given the nature of the data being used and the nature of the relationships we are attempting to observe, $F E$ estimation is not very applicable. Firstly, since $F E$ estimation considers deviations over time from individual country averages and there are only three time periods (themselves five-year averages) under consideration, not much information is left after the $F E$ transformation. Secondly, this transformation makes it difficult to find useful instrumental variables. For example, many of the instruments used in the other regressions are constants. However, these can not explain deviations from time averages of the independent variables, so I am left with poor instrumentation for the $F E$ regressions. For both these reasons, $F E$ estimates do not yield any worthwhile results.
} 
Due to endogeneity problems, instruments are used for high technology imports, non-high technology imports, population, IPRs, and FDI inflows. ${ }^{13}$ Quality adjusted research and transportation and communication infrastructure are both predetermined stock measures. Hence, they enter as their own instruments.

Inclusion of FDI inflows in the regressions reduces the sample size by as much as fifty percent. For that reason Table $1 \mathrm{~A}$ in the appendix presents regression results excluding FDI. The results are broadly consistent with those when FDI is included, the principal exception being the effect of IPRs on imitation.

Imitation and innovation regression results including FDI are presented in Table 1. Columns 1 and 3 present cross-sectional results, while columns 2 and 4 present the $R E$ results, for imitation and innovation respectively. Random effects estimation uses the following transformation of equation (1)

$$
\begin{aligned}
(1 \mathrm{R} . \mathrm{E} .) C_{i t}-\theta \bar{C}_{i}=(1-\theta) \beta_{0}+\beta_{1}\left(R_{i t}-\theta \bar{R}_{i}\right)+\beta_{2}\left(F_{i t}-\theta \bar{F}_{i}\right)+\beta_{3}\left(H_{i t}-\theta \bar{H}_{i}\right)+ \\
\beta_{4}\left(N H_{i t}-\theta \overline{N H}_{i}\right)+\beta_{5}\left(G D P_{i t}-\theta \overline{G D P}_{i}\right)+\left[(1-\theta) \alpha_{i}+\left(\varepsilon_{i}-\theta \bar{\varepsilon}_{i}\right)\right],
\end{aligned}
$$

where variables with bars represent 1970-84 time averages. The weight, $\theta$, used in the above transformation depends on $\sigma_{\alpha}$ and $\sigma_{\varepsilon} \cdot{ }^{14}$ If $\theta=1$, then $R E$ estimation is equivalent to fixed effects estimation. On the other hand, if $\theta=0$, then $R E$ estimation is equivalent to $O L S$ estimation. In the imitation and innovation regressions, $\hat{\theta}=0$, implying that $R E$ yields identical results to pooled $2 S L S$ estimation. Hence, separate pooled $2 S L S$ results are not presented.

The cross-sectional and RE 2SLS imitation regressions yield similar results. Looking at the $R E$ regression, the elasticity of domestic imitation is greatest with respect

\footnotetext{
${ }^{13}$ Earlier import values, the exchange rate, a black market premium, a measure of free trade openness, and measures of tariff and non-tariff restrictions on imports of intermediate inputs and capital goods are all used as instruments for imports. Average population from 1965-69 instruments for population levels. In addition to 1965 IPR levels, instruments suggested by Maskus and Penubarti (1995) are used for the level of IPR protection. These include membership in the Paris Convention and earlier indicators of development such as infant mortality rates and fertility rates, both in 1965. Finally, instruments used for FDI inflows include U.S. FDI and R\&D by U.S. multinationals both in 1966, CPI inflation, 1965 IPR levels, the exchange rate, and own import weighted tariff measures. Results from pooled OLS regressions of each variable on its instruments are presented in the technical appendix.
} 
to the size of the economy (1.8), infrastructure (1.6), high technology imports from DCs (1.4), and quality-adjusted research (1.0). As expected due to the Japanese patent system, the dummy variable for Japan is positive (with a coefficient of almost 3.0) and significant.

High technology imports from DCs are not significantly different from zero in the cross sectional regression, but are highly significant in the $R E$ regression. ${ }^{15}$ Imports of non-high technology goods enter negatively, with a coefficient of -1.3 , and are statistically significant in both imitation regressions. When other measures of openness

Table 1. Innovation and Imitation Regressions (using White's Heteroskedasticity Correction)

\begin{tabular}{|c|c|c|c|c|}
\hline \multirow[t]{2}{*}{$\begin{array}{l}\text { Dependent } \\
\text { Variable }\end{array}$} & \multicolumn{2}{|c|}{$\begin{array}{l}\text { Imitation } \\
\text { Eq. } 1\end{array}$} & \multicolumn{2}{|c|}{$\begin{array}{l}\text { Innovation } \\
\text { Eq. } 2\end{array}$} \\
\hline & $\begin{array}{c}(1) \\
\text { Cross - Section } \\
2 S L S\end{array}$ & $\begin{array}{c}(2) \\
\text { Random Effects } \\
2 S L S \\
(\theta=0) \Rightarrow \text { Pooled } \\
2 S L S\end{array}$ & $\begin{array}{c}(3) \\
\text { Cross - Section } \\
2 S L S\end{array}$ & $\begin{array}{c}(4) \\
\text { Random Effects } \\
2 S L S \\
(\theta=0) \Rightarrow \text { Pooled } \\
2 S L S\end{array}$ \\
\hline Constant & $\begin{array}{l}-2.72 \\
(-1.14)\end{array}$ & $\begin{array}{l}-1.85 \\
(-.508)\end{array}$ & $\begin{array}{l}-.364 \\
(-.067)\end{array}$ & $\begin{array}{c}-.019 \\
(-.005)\end{array}$ \\
\hline $\begin{array}{l}\text { Quality Adj. Research } \\
\text { Effort Per Capita }(R)\end{array}$ & $\begin{array}{c}1.61 * * * * \\
(6.15)\end{array}$ & $\begin{array}{c}1.03 * * * * \\
(4.63)\end{array}$ & $\begin{array}{c}1.16 * * * * \\
(6.20)\end{array}$ & $\begin{array}{c}.865 * * * * \\
(4.30)\end{array}$ \\
\hline $\begin{array}{l}\text { Transp. \& Communic. } \\
\text { Infrastructure Per } \\
\text { Capita }(F)\end{array}$ & $\begin{array}{c}1.72 * * * * \\
(5.14)\end{array}$ & $\begin{array}{c}1.59 * * * * \\
(4.39)\end{array}$ & $\begin{array}{c}.902 \\
(1.59)\end{array}$ & $\begin{array}{l}.408 \\
(.866)\end{array}$ \\
\hline $\begin{array}{l}\text { High Tech. Imports as } \\
\text { Share of GDP }(H)\end{array}$ & $\begin{array}{l}.555 \\
(1.19)\end{array}$ & $\begin{array}{c}1.41 * * * * \\
(3.05)\end{array}$ & $\begin{array}{c}1.34 * * * * \\
(4.69)\end{array}$ & $\begin{array}{l}1.27 * * * * \\
(3.18)\end{array}$ \\
\hline $\begin{array}{l}\text { Non-High Tech. } \\
\text { Imports as Share of } \\
\text { GDP }(\mathrm{NH})\end{array}$ & $\begin{array}{c}-1.37 * * * * \\
(-3.34)\end{array}$ & $\begin{array}{c}-1.29 * * * * \\
(-3.75)\end{array}$ & $\begin{array}{l}-.731 \\
(-1.18)\end{array}$ & $\begin{array}{l}-.148 \\
(-.379)\end{array}$ \\
\hline $\begin{array}{l}\text { Foreign Direct Invest. } \\
\text { as Share of GDP }(F D I)\end{array}$ & $\begin{array}{l}-3.38 \\
(-.915)\end{array}$ & $\begin{array}{l}-3.14 \\
(-.731)\end{array}$ & $\begin{array}{l}-7.48^{* *} \\
(-2.06)\end{array}$ & $\begin{array}{l}-2.98 \\
(-.87)\end{array}$ \\
\hline${ }^{14}$ Specifically, $\theta=1-\frac{1}{(}$ & $\frac{\sigma_{\varepsilon}}{\left.+\sigma_{\varepsilon}^{2}\right)^{1 / 2}}$, whe & $\Gamma=$ number of tim & riods. & \\
\hline
\end{tabular}




\begin{tabular}{|c|c|c|c|c|}
\hline Population $(P O P)$ & $\begin{array}{c}1.68 * * * * \\
(9.12)\end{array}$ & $\begin{array}{c}1.76 * * * * \\
(7.75)\end{array}$ & $\begin{array}{c}1.70 * * * * \\
(4.54)\end{array}$ & $\begin{array}{c}1.76 * * * * \\
(5.90)\end{array}$ \\
\hline $\begin{array}{l}\text { Intellectual Property } \\
\text { Rights }(P)\end{array}$ & $\begin{array}{c}-.948 * * * \\
(-2.62)\end{array}$ & $\begin{array}{l}-.733 * * \\
(-1.83)\end{array}$ & $\begin{array}{l}.639 \\
(1.08)\end{array}$ & $\begin{array}{l}.663^{*} \\
(1.55)\end{array}$ \\
\hline Japan Dummy & $\begin{array}{l}.699 \\
(.574)\end{array}$ & $\begin{array}{c}2.93 * * * * \\
(3.08)\end{array}$ & & \\
\hline $\begin{array}{l}\text { Observations } \\
R^{2} \\
\text { F-Statistic }\end{array}$ & $\begin{array}{l}17 \\
.96 \\
89 \\
\end{array}$ & $\begin{array}{l}39 \\
.86 \\
87 \\
\end{array}$ & $\begin{array}{l}15 \\
.94 \\
44 \\
\end{array}$ & $\begin{array}{l}35 \\
.84 \\
28 \\
\end{array}$ \\
\hline $\begin{array}{l}* * * * \text { Significant at the } \\
\text { All variables are in nat }\end{array}$ & $\begin{array}{l}\text { dence lev } \\
\text { rithms. }\end{array}$ & $\begin{array}{l}* * * 5 \% \\
t \text {-statisti }\end{array}$ & $\begin{array}{l}* * 10 \% \\
\text { parentheses. }\end{array}$ & $5 \%$ \\
\hline
\end{tabular}

are considered instead of imports of non-high technology goods, similar negative and significant coefficient estimates result. ${ }^{16}$

The negative coefficient on general measures of openness, combined with positive coefficient on imports of high technology goods may reflect different effects of trade on imitation. For example, imports of high technology goods theoretically contribute to imitation by lowering costs of reverse engineering. However, once that component is controlled for using high technology imports, openness in general will imply that imitated goods will have to compete in the domestic market with the original inventions. Hence, general openness may lower the amount of domestic imitation. ${ }^{17}$ IPRs also negatively affect domestic imitation. This result is consistent with the intuition that higher domestic IPRs make domestic imitation more difficult. ${ }^{18}$

A final interesting result is that even though many point to FDI inflows as contributing positively to technological diffusion, FDI inflows do not appear to contribute to domestic imitation. While this may be due to the rather poor quality of the FDI data, this result complements work by Lichtenberg and van Pottelsberghe de la Potterie (1996),

\footnotetext{
16 These measures include exports plus imports as a share of nominal GDP and Lee's free trade openness measure based negatively on the average distance to the capitals of the 20 major world exporters and the size of the land surface in the home country.

17 Only when Sachs and Warner's dummy for openness is considered does this variable enter positively and significantly. High technology imports nonetheless continue to be positive and significant.

18 However, too much emphasis should not be placed on this result since IPRs enter positively and marginally significantly in the regressions presented in Table $1 \mathrm{~A}$ of the appendix that do not include FDI inflows but consequently include a larger sample of countries.
} 
which finds no relationship between FDI inflows and international R\&D spillovers, ${ }^{19}$ and work by Haddad and Harrison (1993), which finds no relationship between productivity growth of domestic firms and the presence of foreign firms. ${ }^{20}$

The cross-section and $R E$ innovation regressions results are presented in columns 3 and 4 of Table 1. As expected, market size, quality-adjusted research, and IPRs all contribute positively to domestic innovation with coefficients of approximately 1.8, 0.9, and 0.7 , respectively. High technology imports from DCs also positively contribute to innovation with a coefficient of approximately 1.3 whether one considers the cross-section or $R E$ results. $^{21}$ Imports of all other goods enter negatively, but are not statistically significant. Again, high technology imports may contribute positively to innovative activity since reverse engineering the lead good may be a precursor to eventual invention of the next quality level. However, general openness may no longer matter since truly innovative domestic firms can successfully compete with foreign imports.

In contrast to the imitation regressions, transportation and communications infrastructure does not appear to play a role in domestic innovation. These results suggest that such infrastructure is far more important to imitative firms than innovative firms. However, similarly to the imitation regressions, FDI inflows do not contribute to domestic innovation in the $R E$ regression. In fact, the only time that FDI inflows are statistically significant (in the cross-section innovation regression), they enter negatively. This might suggest a strategic role whereby multinationals preemptively establish themselves in a country to say take advantage of lower costs of production, while at the same time discouraging local firms from participating in that particular industry.

\footnotetext{
${ }^{19}$ In fact, Lichtenberg and van Pottelsberghe find that outward FDI appears to be a mechanism by which countries gain the technology of the host country.

${ }^{20}$ Related to this question, Mansfield and Romeo (1980) surveyed 26 randomly selected cases of technology transfer from U.S. firms to non-U.S. competitors. About two-thirds of the U.S. firms felt that the transfer of the technology to overseas subsidiaries had little or no impact on the speed with which the technology spread to non-U.S. competitors. The reason for this was that technology tended to "leak out" through other means. Most firms felt that reverse engineering was the most important channel through which technology diffused. Other channels mentioned were information provided by patents and the hiring away of personnel employed by the subsidiary.

21 If quality-adjusted research is interacted with high technology imports, its coefficient is .97 and significant at the $1 \%$ confidence level, without greatly affecting the remaining results of the regression.
} 
A consistent finding of these regressions is that regardless of the estimation technique, high technology imports from DCs are (with only one exception) always found to contribute positively both to domestic innovation and imitation. Furthermore, the coefficient estimate on high technology imports is consistently about 1.3 for all innovation regressions and ranges between 0.6 and 1.4 for the imitation regressions. Since the variables are in natural logarithms, these coefficient estimates represent the elasticities of domestic innovation and imitation with respect to high technology imports. Assuming initial rates of domestic innovation and imitation of $1 \%$, this implies that a sustained $10 \%$ increase in imports of high technology capital goods would have raised the domestic innovation rate to $1.13 \%$ and the imitation rate to $1.14 \%$ during that same period, all else equal. ${ }^{22}$

\section{Per Capita GDP Growth}

We now turn to the question of how foreign and domestic technology affect growth. ${ }^{23}$ To analyze the contributing factors to real per capita GDP growth, theory suggests considering the following relationship

$$
\gamma_{Y_{i t}}=\beta_{0}+\beta_{1} Y_{i, t_{-} l}+\beta_{2} \gamma_{K_{i t}}+\beta_{3} I_{i t}+\beta_{4} C_{i t}+\beta_{5} \gamma_{H_{i t}}+\mu_{i t},
$$

where $\mu_{i t}=\alpha_{i}+\varepsilon_{i t}$. However, due to collinearity between the innovation and imitation proxies, the imitation proxy is not included in the regressions that follow. ${ }^{24}$ Previously

\footnotetext{
${ }^{22}$ These results complement Ben-David's (1996) findings that trade-based country groupings are more likely to converge than randomly selected country groupings and Ben-David and Rahman's (1996) findings that trade-based country groupings are more likely to have total factor productivity convergence than randomly selected country groupings. Hence their findings, as well as the findings in this paper, suggest that trade plays an important role in technological diffusion and, in turn, conditional convergence. 23 To include more countries in the growth regressions, the proxy for domestic innovation is redefined as U.S. patents granted to residents of a given country plus one. Then the natural log of the innovation proxy is zero for countries with no U.S. patents, rather than being undefined and dropped from the regression.

${ }^{24}$ Inclusion of the imitation proxy destroys all reasonable results. For example, when imitation is included, capital stock growth negatively affects GDP growth.
} 
described instruments are used for high technology imports and exogenous variables from the previous innovation regressions are employed to instrument for domestic innovation. ${ }^{25}$

As shown in Table 2, all the explanatory variables have the expected signs and are statistically significant (with the exception of domestic innovation, which is not significant in the cross-sectional regression). Initial 1969 per capita GDP enters negatively, supporting the notion of conditional convergence. ${ }^{26}$ Growth of physical capital, with an estimated coefficient of 0.3 , has by far the greatest effect on real per capita GDP growth. Both growth of per capita high technology imports from DCs, and domestic innovation contribute positively to domestic per capita GDP growth with estimated coefficients of approximately 0.1 and 0.002 , respectively. ${ }^{27}$

If the innovation proxy is an accurate measure of domestic innovation and growth of per capita high technology imports from DCs is a reasonable proxy for the influence of developed nations' innovations on the domestic economy, this suggests that innovations from DCs have a far greater effect on domestic growth than do domestic innovations. ${ }^{28}$ Additionally, if this regression is run on the DCs and LDCs separately, we see that domestic innovation is statistically significant in explaining real per capita GDP growth in the LDCs but not in the DCs. ${ }^{29}$

To verify if imports of high technology goods are more important to LDCs than to DCs, columns 3 and 4 of Table 2 present results that include a dummy for DCs, as well as

Table 2. Growth Regressions

Eq. (3') (using White's Heteroskedasticity Correction)

\footnotetext{
25 In particular, average innovation from 1965 to 1969, the per capita transportation and communication stock, quality-adjusted research, and 1965 IPRs are used as instruments for domestic innovation.

26 This is similar to Barro and Sala-i-Martin's (1991) findings of conditional convergence between states of the United States.

27 These results are robust to the inclusion of growth of human capital (the average number of schooling years in the total population over age 25 (Barro and Lee 1993) and measures of openness (Sachs and Warner's index or exports plus imports as a share of GDP). Openness measures contribute positively and significantly to per capita GDP growth. Human capital growth on the other hand, is not statistically significant. Inclusion of these variables does not greatly affect the coefficient estimates for the other variables, with the exception of domestic innovation, which is no longer significantly different from zero.

${ }^{28}$ Furthermore, since the measure of high technology imports is based in part on capital goods, growth in this term should positively affect GDP growth.

29 This finding is broadly consistent with the Eaton and Kortum (1996) finding that with the exception of the United States, the $O E C D$ countries derive almost all of their productivity growth from abroad.
} 


\section{Dependent Variable: Growth of Real GDP Per Capita $(Y)$}

\begin{tabular}{|c|c|c|c|c|}
\hline & $\begin{array}{c}(1) \\
\text { Cross-Section } \\
\text { (Between) } \\
2 S L S\end{array}$ & $\begin{array}{c}(2) \\
\text { Random Effects } \\
2 S L S \\
(\theta=0) \Rightarrow \text { same as } \\
\text { pooled } 2 S L S\end{array}$ & $\begin{array}{c}(3) \\
\text { Cross-Section } \\
\text { (Between) } \\
2 S L S\end{array}$ & \begin{tabular}{|c|}
$(4)$ \\
Random Effects \\
$2 S L S$ \\
$(\theta=0) \Rightarrow$ same as \\
pooled $2 S L S$ \\
\end{tabular} \\
\hline Constant & $\begin{array}{l}.09 * * * \\
(2.24)\end{array}$ & $\begin{array}{c}.083 * * * * \\
(2.91)\end{array}$ & $\begin{array}{c}.133 * * * * \\
(5.01)\end{array}$ & $\begin{array}{c}.116 * * * * \\
(3.75)\end{array}$ \\
\hline $\begin{array}{l}1969 \text { GDP per capita } \\
\left(Y_{t-1}\right)\end{array}$ & $\begin{array}{l}-.01 * * * \\
(-2.03)\end{array}$ & $\begin{array}{c}-.01 * * * * \\
(-2.62)\end{array}$ & $\begin{array}{c}-.017 * * * * \\
(-4.62)\end{array}$ & $\begin{array}{c}-.015 * * * * \\
(-3.62)\end{array}$ \\
\hline $\begin{array}{l}\text { Growth of per capita } \\
\text { Capital Stock }(K)\end{array}$ & $\begin{array}{c}.393 * * * * \\
(3.17)\end{array}$ & $\begin{array}{c}.303 * * * * \\
(3.59)\end{array}$ & $\begin{array}{l}.337 * * * \\
(2.40)\end{array}$ & $\begin{array}{c}.369 * * * * \\
(5.17)\end{array}$ \\
\hline $\begin{array}{l}\text { Growth of per capita } \\
\text { High Tech. Imports }(H)\end{array}$ & $\begin{array}{l}.141 * * \\
(1.97)\end{array}$ & $\begin{array}{c}.096 * * * * \\
(3.77)\end{array}$ & $\begin{array}{c}.161 * * * \\
(2.35)\end{array}$ & $\begin{array}{c}.142 * * * * \\
(3.64)\end{array}$ \\
\hline Domestic Innovation $(I)$ & $\begin{array}{c}.002 \\
(.983)\end{array}$ & $\begin{array}{c}.002 * * * \\
(1.95)\end{array}$ & $\begin{array}{c}.004 * * * \\
(2.04)\end{array}$ & $\begin{array}{c}.003 * * * \\
(2.16)\end{array}$ \\
\hline DC Dummy & & & $\begin{array}{c}.015 * * * * \\
(3.18)\end{array}$ & $\begin{array}{c}.015^{* * *} \\
(2.07)\end{array}$ \\
\hline $\begin{array}{l}\text { DC* Growth of per } \\
\text { capita High Tech. } \\
\text { Imports }(D C H)\end{array}$ & & & $\begin{array}{l}-.383^{* *} \\
(-1.97)\end{array}$ & $\begin{array}{c}-.268 * * * \\
(-2.33)\end{array}$ \\
\hline $\begin{array}{l}\text { Obsservations } \\
R^{2}\end{array}$ & $\begin{array}{l}33 \\
.68 \\
\end{array}$ & $\begin{array}{l}111 \\
.53 \\
\end{array}$ & $\begin{array}{l}33 \\
.73 \\
\end{array}$ & $\begin{array}{r}111 \\
.49 \\
\end{array}$ \\
\hline
\end{tabular}

$* * * *$ Significant at the $1 \%$ confidence level. $* * * 5 \%$ conf. level. $* * 10 \%$ conf. level. $* 15 \%$ conf. level. All variables are in natural logarithms. $t$-statistics are in parentheses.

an interaction term between the DC dummy and growth of high technology imports. As expected, these results show that DCs tend to grow more quickly than LDCs. More interestingly, when growth of high technology imports is separated into a general component and the marginal change when considering a DC, the elasticity of GDP growth with respect to growth of high technology imports increases to 0.14 , while the marginal contribution to this elasticity when a country is a DC is $-0.27 .{ }^{30}$ Hence, the positive link between foreign technology (coming through trade in physical goods) and growth is driven by the LDCs in the sample, rather than the DCs.

\footnotetext{
${ }^{30}$ In fact, the estimated elasticity for the DCs is negative. Still, when this regression is run including only DCs, high technology imports enter positively and significantly (although the overall regression is poor).
} 


\section{Conclusion}

This paper finds general support for the role of imports of high technology goods from developed countries in the international diffusion of technology. In particular, domestic imitation and innovation both consistently depend positively on high technology imports from developed countries. However, foreign direct investment inflows, often considered important mechanisms for technological diffusion to developing nations, do not significantly affect either domestic innovation or imitation. In turn, growth in real per capita GDP is positively related to both foreign and domestic innovation. Foreign technology from developed countries contributes more to per capita GDP growth than domestic innovation, suggesting that new foreign technology is applied directly to production, in addition to leading to increased domestic innovation and imitation.

These results are consistent with the idea that trade with developed countries benefits less developed countries via both static effects and dynamic externalities. This is due to evidence that high technology good imports from developed countries not only positively affect domestic innovation, but also lead to increased GDP growth as higher quality capital goods are used in domestic production. Thus, trade is a mechanism by which more advanced foreign technology can be used to the advantage of a less developed country, not only to boost domestic innovation, but also as a means of benefiting from continued foreign innovation.

\section{Appendix}

\section{Countries Included in Regressions}

$\begin{array}{lllll}\begin{array}{l}\text { Imitation } \\ \text { Regression } \\ \text { without } \boldsymbol{F D I}\end{array} & \begin{array}{l}\text { Imitation } \\ \text { Regression with } \\ \text { FDI }\end{array} & \begin{array}{l}\text { Innovation } \\ \text { Regression } \\ \text { without } \boldsymbol{F D I}\end{array} & \begin{array}{l}\text { Innovation } \\ \text { Regression with } \\ \text { FDI }\end{array} & \begin{array}{l}\text { Growth } \\ \text { Regression }\end{array} \\ \text { Argentina } & \text { Argentina } & \text { Argentina } & \text { Argentina } & \text { Argentina } \\ \text { Austria } & \text { Belgium-Lux. } & \text { Austria } & \text { Belgium-Lux. } & \text { Austria } \\ \text { Belgium-Lux. } & \text { Brazil } & \text { Belgium-Lux. } & \text { Brazil } & \text { Belgium-Lux. } \\ \text { Bolivia } & \text { Chile } & \text { Brazil } & \text { Canada } & \text { Bolivia } \\ \text { Brazil } & \text { Denmark } & \text { Canada } & \text { Denmark } & \text { Brazil } \\ \text { Chile } & \text { France-Monaco } & \text { Denmark } & \text { France-Monaco } & \text { Canada } \\ \text { Costa Rica } & \text { Germany } & \text { Finland } & \text { Germany } & \text { Chile } \\ \text { Denmark } & \text { Italy } & \text { France-Monaco } & \text { Italy } & \text { Costa Rica } \\ \text { Egypt } & \text { Japan } & \text { Germany } & \text { Japan } & \text { Denmark }\end{array}$




\begin{tabular}{|c|c|c|c|c|}
\hline Finland & Mexico & Italy & Mexico & Egypt \\
\hline France-Monaco & Netherlands & Japan & Netherlands & El Salvador \\
\hline Germany & Norway & Korea, Rep. & Norway & Finland \\
\hline Greece & Philippines & Mexico & Sweden & France-Monaco \\
\hline Guatemala & Sweden & Netherlands & Switzerland & Germany \\
\hline Italy & Switzerland & Norway & United Kingdom & Ghana \\
\hline Japan & United Kingdom & Spain & & Greece \\
\hline Korea, Rep. & Venezuela & Sweden & & Guatemala \\
\hline Mexico & & Switzerland & & Indonesia \\
\hline Netherlands & & United Kingdom & & Iran \\
\hline Norway & & U.S.A. & & Italy \\
\hline Pakistan & & & & Japan \\
\hline Philippines & & & & Jordan \\
\hline Singapore & & & & Malawi \\
\hline Spain & & & & Malaysia \\
\hline Sweden & & & & Mexico \\
\hline Switzerland & & & & Netherlands \\
\hline Tunisia & & & & Nicaragua \\
\hline Turkey & & & & Norway \\
\hline United Kingdom & & & & Pakistan \\
\hline Venezuela & & & & Philippines \\
\hline & & & & Singapore \\
\hline & & & & Spain \\
\hline & & & & Sweden \\
\hline & & & & Switzerland \\
\hline & & & & Thailand \\
\hline & & & & Tunisia \\
\hline & & & & Turkey \\
\hline & & & & United Kingdom \\
\hline & & & & U.S.A. \\
\hline & & & & Venezuela \\
\hline 30 Countries & 17 Countries & 20 Countries & 15 Countries & 40 Countries \\
\hline
\end{tabular}




\section{Figure 1. Imitation and High Technology Imports From DCs 1970-74, 1975-79, 1980-84}

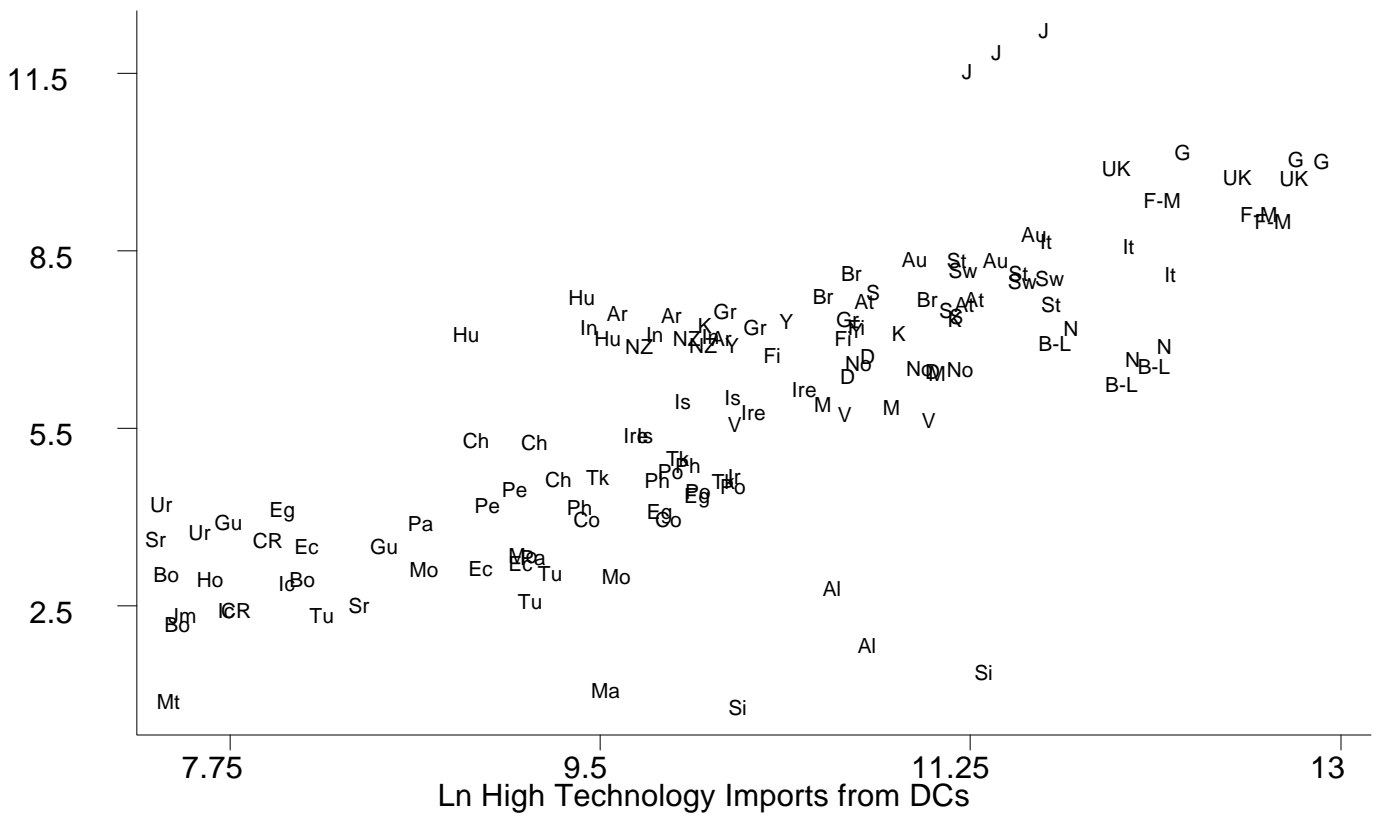

Sources: Commodity Trade Statistics, U.N.

Industrial Property Statistics, World Intellectual Property Organization.

\section{Data}

\section{High Technology Imports}

A measure of high technology imports from DCs is created using data from various issues of the Commodity Trade Statistics published by the United Nations. ${ }^{31}$ The commodity groups used in this measurement include Standard International Trade Classes 7, 86, and 89 (SITC, Rev. 1). Class 7 includes machinery and transport equipment. Class 86 includes instruments (optical, medical, and photographic), watches and clocks. Finally, class 89 includes "miscellaneous manufactured goods" which include sound recorders, musical instruments, toys, and office supplies (which in later years include computers). ${ }^{32}$ These data are reported in current U.S. dollar terms. To express the data in real terms (1985 \$U.S.), I deflate by the U.S. Producer Price Index (PPI), for machinery and transport equipment, which are consolidated under the category of capital equipment in more recent years.

Earlier import values, the exchange rate [Summers and Heston (SH) 1991 v. 5.0], the black market premium [Wood 1988 and the World Bank 1991] ${ }^{33}$, a measure of free trade openness, and measures of tariff and non-tariff restrictions on imports of intermediate inputs and capital goods [Lee 1993] are all used as instrumental variables for imports.

31 During this time period, the U.N. lists the following countries as DCs: Australia, Austria, BelgiumLuxembourg, Canada, Denmark, Finland, France, Germany (Fed. Rep.), Greece, Iceland, Ireland, Israel, Italy, Japan, the Netherlands, New Zealand, Norway, Portugal, the South African Customs Union, Spain, Sweden, Switzerland, the United Kingdom, the United States, and Yugoslavia.

${ }^{32}$ The OECD classifies the following as high technology industries: drugs and medicines (ISIC 3522), office machinery and computers (ISIC 3825), electrical machinery (ISIC 383, excluding 3832), electronic components (ISIC 3832), aerospace (ISIC 3845), and scientific instruments (ISIC 385) (Abbott 1991).

33 The black market premium is the black market exchange rate/official exchange rate ratio minus one. 


\section{Non-High Technology Imports}

Non-high technology imports are measured as total imports, excluding high technology goods imported from DCs. The 1985 real value of high technology imports, is subtracted from 1985 real level of total imports from the Penn World Table (v.5.0). Earlier values, along with the instruments for imports described above are used as instruments for non-high technology imports.

\section{Intellectual Property Rights}

Since the innovation and imitation proxies are based on patent data, it is important to control for varying enforcement of IPRs across countries. To this end, I use a time varying index of IPRs enforcement developed by Park and Ginarte (1997) for 110 countries. This index is based on five categories of patent laws: extent of coverage, membership in international patent agreements, provisions for loss of protection, enforcement mechanisms, and the duration of protection. ${ }^{34}$

In addition to 1965 IPR levels, I use several instruments suggested by Maskus and Penubarti (1995) when considering the Rapp and Rozek (1990) index. These include an alternative measure of IPRs such as membership in the Paris Convention, and earlier indicators of development such as infant mortality rates and fertility rates [World Bank], both in 1965.

\section{Quality-Adjusted Research}

To reflect not only the research effort by scientists, but also the quality of their efforts, I create a measure called quality-adjusted research. It is defined as the number of $R \& D$ personnel per capita employed in research, multiplied by the average years of higher education for the population over the age of 25. Data on $R \& D$ personnel employed in research come from various annual UNESCO Statistical Yearbooks. Education data are from Barro and Lee (1993).

\section{Capital Stock}

Using initial capital stock estimates from Benhabib and Spiegel (1994), ${ }^{35}$ along with investment flows given in the Penn World Table (v5.6), I derive capital stock estimates for subsequent years. The capital stock is scaled using population data from SH (1991).

\section{Transportation and Communication Infrastructure}

Estimates for the stock of communication and transportation infrastructure are derived according to the perpetual inventory method using government expenditures on roads, and other transportation and communication infrastructure as reported in annual issues of Government Financial Statistics (GFS). Initial 1965 stock estimates are based on Benhabib and Spiegel's (1994) 1965 capital stock estimates multiplied by the average fraction of total domestic investment made by the government in roads, other transport equipment and communication capital between 1972 and 1985. This yields an estimate of the 1965 stock of transportation and communication capital to which annual government investments in roads,

34 The Park and Ginarte index has two main advantages over other time-invariant indices of intellectual property rights (Rapp and Rozek 1990; Mansfield 1994). Firstly, it covers more countries and a larger time period than the other indices, since it follows these countries over five-year periods from 1960 to 1990. Secondly, the index considers broader categories of the patent system, consequently yielding greater variability in the measurement of $I P R$ s across countries.

35 Using the SH (1991) data on investment flows and capital stocks for a limited sample of 29 countries in 1980 and 1985, Benhabib and Spiegel estimate the capital stock coefficient in a standard three factor aggregate production function with constant returns to scale. They then use this coefficient to estimate initial capital stocks in 1965 for the remaining countries in the data set. 
other transport equipment and communication capital can be added according to the perpetual inventory method. The stock of transportation and communication infrastructure is scaled using population data from SH (1991). Since GFS do not include the necessary Japanese data, I generated the Japanese infrastructure stock using data on government expenditures in annual issues of the Japan Statistical Yearbook.

\section{Foreign Direct Investment}

Data on FDI inflows come from International Financial Statistics, IMF, line 78 bed. The instruments used for FDI inflows include U.S. FDI and R\&D by U.S. multinationals both in 1966, CPI inflation (WB Development Indicators, 1996), 1965 IPRs (Park and Ginarte, 1997), the exchange rate, and own import weighted tariff measures (Lee, 1993).

\section{Real GDP}

Data on real GDP per capita in constant dollars (expressed in 1985 international prices) come from the Penn World Table (v. 5.6) in SH (1991). ${ }^{36}$

\section{Population}

Population data also come from the Penn World Table. Average population from 1965-69 is used to instrument for population. For $F E$ regressions a time trend is used as an instrument for population.

\footnotetext{
${ }^{36} \mathrm{SH}$ (1991) created this data set using a series of benchmark studies by the United Nations International Comparison Program (ICP). These studies attempted to report prices of identical goods and services in participating countries. From the reported prices, estimates of price parities were created and then used to convert national currency expenditures into a common currency unit. It is important to note that these studies actually presented cross-sectional data on prices for between 16 and 60 countries during four specific years, 1970, 1975, 1980 and 1985. The Penn World Table estimates are therefore based on extrapolations of the cross-section comparisons, in order to include additional countries and dates. Hence these estimates will undoubtedly be mismeasured. Nonetheless, this is the only data set which allows for real comparisons across countries.
} 


\section{Table 1A. Innovation and Imitation Regressions Excluding FDI}

(using White's Heteroskedasticity Correction)

\begin{tabular}{|c|c|c|c|c|c|c|}
\hline \multirow[t]{2}{*}{$\begin{array}{l}\text { Dependent } \\
\text { Variable }\end{array}$} & \multicolumn{3}{|c|}{$\begin{array}{l}\text { Imitation } \\
\text { Eq. } 1\end{array}$} & \multicolumn{3}{|c|}{$\begin{array}{c}\text { Innovation } \\
\text { Eq. } 2\end{array}$} \\
\hline & $\begin{array}{l}(1) \\
\text { Pooled } \\
2 S L S\end{array}$ & $\begin{array}{c}(2) \\
\text { Cross - } \\
\text { Section } \\
2 S L S\end{array}$ & $\begin{array}{c}(3) \\
\text { Random } \\
\text { Effects } \\
2 S L S \\
(\theta=.687)\end{array}$ & $\begin{array}{l}(4) \\
\text { Pooled } \\
2 S L S\end{array}$ & $\begin{array}{c}(5) \\
\text { Cross - } \\
\text { Section } \\
2 S L S\end{array}$ & $\begin{array}{c}(6) \\
\text { Random } \\
\text { Effects } \\
2 S L S \\
(\theta=.59)\end{array}$ \\
\hline Constant & $\begin{array}{l}-2.32 \\
(-.854)\end{array}$ & $\begin{array}{l}-.084 \\
(4.44)\end{array}$ & $\begin{array}{l}-1.06 \\
(-.844)\end{array}$ & $\begin{array}{l}-5.44 * \\
(-1.47)\end{array}$ & $\begin{array}{c}-2.42 \\
(-.0535)\end{array}$ & $\begin{array}{c}1.67 \\
(.785)\end{array}$ \\
\hline $\begin{array}{l}\text { Quality Adj. Research } \\
\text { Effort Per Capita }(R)\end{array}$ & $\begin{array}{c}.366 * * * * \\
(2.51)\end{array}$ & $\begin{array}{l}.564 * * \\
(1.95)\end{array}$ & $\begin{array}{l}-.253 \\
(-1.42)\end{array}$ & $\begin{array}{c}.559 * * * * \\
(5.31)\end{array}$ & $\begin{array}{c}.726 * * * * \\
(4.30)\end{array}$ & $\begin{array}{l}.044 \\
(.228)\end{array}$ \\
\hline $\begin{array}{l}\text { Transp. \& Communic. } \\
\text { Infrastructure }(F)\end{array}$ & $\begin{array}{l}.822 * * * * \\
(5.02)\end{array}$ & $\begin{array}{c}.748 * * * * \\
(3.27)\end{array}$ & $\begin{array}{c}.844 * * * \\
(2.36)\end{array}$ & $\begin{array}{c}.850 * * * \\
(2.15)\end{array}$ & $\begin{array}{c}.640 \\
(1.37)\end{array}$ & $\begin{array}{l}-.741 \\
(-.966)\end{array}$ \\
\hline $\begin{array}{l}\text { High Tech. Imports as } \\
\text { Share of GDP }(H)\end{array}$ & $\begin{array}{c}1.05^{* * * *} \\
(2.40)\end{array}$ & $\begin{array}{c}1.19 \\
(1.48)\end{array}$ & $\begin{array}{c}1.91 * * * * \\
(3.04)\end{array}$ & $\begin{array}{c}.990 * * * * \\
(2.55)\end{array}$ & $\begin{array}{l}.909 * * \\
(1.97)\end{array}$ & $\begin{array}{c}1.66^{* * * *} \\
(2.30)\end{array}$ \\
\hline $\begin{array}{l}\text { Non-High Tech. } \\
\text { Imports as Share of } \\
\text { GDP }(\mathrm{NH})\end{array}$ & $\begin{array}{c}-.997 * * * * \\
(-3.64)\end{array}$ & $\begin{array}{c}-1.02 * * * * \\
(-3.64)\end{array}$ & $\begin{array}{l}-1.07 * \\
(1.59)\end{array}$ & $\begin{array}{l}-.639^{* *} \\
(-1.95)\end{array}$ & $\begin{array}{c}-.578 \\
(-1.28)\end{array}$ & $\begin{array}{l}.399 \\
(.512)\end{array}$ \\
\hline Population (POP) & $\begin{array}{c}1.14 * * * * \\
(6.12)\end{array}$ & $\begin{array}{c}1.30 * * * * \\
(4.88)\end{array}$ & $\begin{array}{c}1.30 * * * * \\
(3.86)\end{array}$ & $\begin{array}{c}1.25 * * * * \\
(5.22)\end{array}$ & $\begin{array}{c}1.20 * * * * \\
(3.99)\end{array}$ & $\begin{array}{c}1.66 * * * * \\
(2.97)\end{array}$ \\
\hline $\begin{array}{l}\text { Intellectual Property } \\
\text { Rights }(P)\end{array}$ & $\begin{array}{c}.736 * * * * \\
(2.75)\end{array}$ & $\begin{array}{l}.579 \\
(1.35)\end{array}$ & $\begin{array}{l}.831^{* *} \\
(1.73)\end{array}$ & $\begin{array}{c}1.31 * * * * \\
(5.34)\end{array}$ & $\begin{array}{c}1.29 * * * * \\
(3.39)\end{array}$ & $\begin{array}{c}1.65 * * * * \\
(2.55)\end{array}$ \\
\hline Japan Dummy & $\begin{array}{c}3.18 * * * * \\
(4.12)\end{array}$ & $\begin{array}{l}2.70 * * \\
(1.96)\end{array}$ & $\begin{array}{c}1.76 * * * * \\
(5.31)\end{array}$ & & & \\
\hline $\begin{array}{l}\text { Observations } \\
R^{2} \\
\text { F-Statistic }\end{array}$ & $\begin{array}{r}84 \\
.79 \\
204\end{array}$ & $\begin{array}{l}26 \\
.85 \\
39\end{array}$ & $\begin{array}{l}78 \\
.41 \\
52\end{array}$ & $\begin{array}{l}58 \\
.82 \\
62\end{array}$ & $\begin{array}{l}19 \\
.92 \\
27\end{array}$ & $\begin{array}{l}57 \\
.36 \\
6\end{array}$ \\
\hline
\end{tabular}

$* * * *$ Significant at the $1 \%$ confidence level. $* * * 5 \%$ conf. level. $* * 10 \%$ conf. level. $* 15 \%$ conf. level. All variables are in natural logarithms. $\quad \mathrm{t}$-statistics are in parentheses. 


\section{References}

Aghion, Philippe and Peter Howitt. "A Model of Growth Through Creative Destruction." Econometrica. 60, No. 2 (March 1992): 323-51.

Abbot, T.A., "Measuring High-Technology Trade: Contrasting International Trade Administration and Bureau of Census Methodologies and Results," Journal of Economic and Social Measurement. 17 (1991): 17-44.

Barro, Robert and Jong-Wha Lee. "International Comparisons of Educational Attainment." Journal of Monetary Economics. 32 (1993): 363-394.

Barro, Robert and Xavier Sala-i-Martin. "Convergence across States and Regions." Brookings Papers on Economic Activity, No. 1 (1991): 107-182.

. Economic Growth. New York: McGraw-Hill, Inc. (1995).

. "Technological Diffusion, Convergence, and Growth.” Journal of Economic Growth. 2 (1)

(March 1997): 1-26.

Ben-David, Dan. "Trade and Convergence Among Countries." Journal of International Economics. 40 (1996): 279-98.

Ben-David, Dan and A.K.M. Atiqur Rahman. "Technological Convergence and International Trade." University of Houston Working Paper. (1996).

Benhabib, Jess and Mark Spiegel. "The Role of Human Capital in Economic Development: Evidence from Aggregate Cross-Country Data." Journal of Monetary Economics. 34 (1994): 143-173.

Coe, David T. and Elhanan Helpman. "International R\&D Spillovers." European Economic Review. 39 (5) (May 1995): 859-87.

Coe, David T., Elhanan Helpman, and Alexander W. Hoffmaister. "North-South $R \& D$ Spillovers." Economic Journal. 107 (January 1997): 134-49.

Connolly, Michelle. "Learning to Learn: Technological Diffusion Through Trade and Imitation.” Duke University, Department of Economics Working Paper No. 97-25 (1997).

Eaton, Jonathan and Samuel Kortum. "International Patenting and Technology Diffusion.” NBER working paper \#4931 (November 1994).

Eaton, Jonathan and Samuel Kortum. "Trade in Ideas: Patenting and Productivity in the OECD." Journal of International Economics. 40 (3-4) (May 1996a): 251-78.

Eaton, Jonathan and Samuel Kortum. "Measuring Technology Diffusion and the International Sources of Growth." Eastern Economic Journal. 22 (4) (Fall 1996b): 401-410.

Grossman, Gene and Elhanan Helpman. Innovation and Growth in the Global Economy. Cambridge, Massachusetts: MIT Press, 1991a.

_. "Quality Ladders and Product Cycles.” Quarterly Journal of Economics. May (1991b): 557-86.

Haddad, Mona and Ann Harrison. "Are There Positive Spillovers from Direct Foreign Investment?:

Evidence from Panel Data for Morocco.” Journal of Development Economics. 42 (1993): 51-74. 
Keller, Wolfgang. "Are International $R \& D$ Spillovers Trade-Related? Analyzing Spillovers Among Randomly Matched Trade Partners.” NBER working paper \#6065 (June 1997).

Lee, Jong-Wha. "International Trade, Distortions, and Long-Run Economic Growth." IMF Staff Papers. 40, No. 2 (June 1993): 299-328.

Lichtenberg, Frank and Bruno van Pottelsberghe de la Potterie. "International $R \& D$ Spillovers: A ReExamination." Working paper (1996).

Mansfield, Edwin. "Intellectual Property Protection, Foreign Direct Investment, and Technology Transfer.” International Finance Discussion Paper No. 19 (1994).

Mansfield, Edwin and Anthony Romeo. Technology Transfer to Overseas Subsidiaries by U.S.-Based Firms," Quarterly Journal of Economics. (December 1980): 737-750.

Mansfield, Edwin, Mark Swartz, and Samuel Wagner. "Imitation Costs and Patents: An Empirical Study.” Economic Journal. 91 (December 1981): 907-918.

Maskus, Keith E. and Mohan Penubarti. "How Trade-Related are Intellectual Property Rights?" Working paper (August 1994).

Nelson, Richard R. and Edmund S. Phelps. "Investment in Humans, Technological Diffusion, and Economic Growth." American Economic Review. 56, No. 2 (May 1966): 69-75.

Okada, Y. "Tokkyoseido no Ho to Keizaigaku." (“The Law and Economics of the Patent System.") Staff Paper, Shinshu University (1992).

Park, Walter and Juan Carlos Ginarte. "Determinants of Intellectual Property Rights: A Cross-National Survey." Research Policy. forthcoming (1997).

Rapp, Richard T. and Richard P. Rozek. "Benefits and Costs of Intellectual Property Protection in Developing Countries." NERA working paper No. 3 (June 1990).

Sachs, Jeffrey and Andrew Warner. "Economic Reform and the Process of Global Integration." Brookings Papers on Economic Activity. No. 1 (1995), 1-118.

Summers, Robert and Alan Heston. "The Penn World Table (Mark 5): an Expanded Set of International Comparisons, 1950-1988." Quarterly Journal of Economics. 106, No. 2 (May 1991) 327-368.

United Nations. Commodity Trade Statistics. Annual issues (1963 - 1993).

UNESCO, Statistical Yearbooks. various issues.

Wang, Jianmao and Bin Xu. “Trade, FDI, and R\&D Spillovers in the OECD.” University of Florida working paper (1997).

Wood, A. "Global Trends in Real Exchange Rates, 1960 to 1984," World Bank (1988).

World Bank. World Development Report Data Set. (1991).

World Intellectual Property Rights Organization. Industrial Property Statistics. Annual Issues. 
World Intellectual Property Rights Organization. One Hundred Years Protection of Industrial Property. Geneva (1983). 


\section{Technical Appendix}

\section{Instruments}

Dependent Variable: High Technology Imports from DCs as a share of GDP OLS Regression

\begin{tabular}{|l|c|c|c|c|c|c|c|}
\hline Instrument: & $\begin{array}{c}\text { HIMSH } \\
65-69\end{array}$ & $\begin{array}{c}\text { Exch. } \\
\text { Rate }\end{array}$ & $\begin{array}{c}\text { Black } \\
\text { Mkt. } \\
\text { Prem. }\end{array}$ & Freeop & OWTI & OWQI & Constant \\
\hline Coefficient: & .740 & -.034 & -.524 & 1.74 & -.661 & -.323 & -1.88 \\
\hline T-Statistic: & 13.64 & -2.33 & -3.52 & 3.49 & -3.59 & -2.61 & -3.71 \\
\hline
\end{tabular}

\begin{tabular}{|l|l|l|l|l|c|}
\hline Adj. $\mathrm{R}^{2}:$ & .84 & F Statistic: & 130 & Obs.: & 154 \\
\hline
\end{tabular}

\section{Dependent Variable: Non-High Technology Imports as a share of GDP OLS Regression}

\begin{tabular}{|l|c|c|c|c|c|c|c|}
\hline Instrument: & $\begin{array}{c}\text { IMSH 65- } \\
69\end{array}$ & $\begin{array}{c}\text { Exch. } \\
\text { Rate }\end{array}$ & $\begin{array}{c}\text { Black } \\
\text { Mkt. } \\
\text { Prem. }\end{array}$ & Freeop & OWTI & OWQI & Constant \\
\hline Coefficient: & .776 & .028 & -.325 & 1.78 & -.392 & -.132 & -.503 \\
\hline T-Statistic: & 16.8 & 2.95 & -3.37 & 4.39 & -3.36 & -1.59 & -2.81 \\
\hline
\end{tabular}

Dependent Variable: Intellectual Property Rights (Park and Ginarte Index) OLS Regression

\begin{tabular}{|l|c|c|c|c|c|}
\hline Instrument: & IPR65 & Paris Conv. & Fertility 65 & Mortality 65 & Constant \\
\hline Coefficient: & .951 & .342 & -.183 & -.034 & .137 \\
\hline T-Statistic: & 27 & 6.62 & -1.90 & -.79 & .50 \\
\hline \multicolumn{5}{|l|}{} \\
\hline Adj. $\mathbf{R}^{2}:$ & .88 & F Statistic: & 371 & Obs.: & 201 \\
\hline
\end{tabular}

Dependent Variable: Foreign Direct Investment as a Share of GDP

OLS Regression

\begin{tabular}{|l|c|c|c|c|c|c|c|}
\hline Instrument: & $\begin{array}{c}\text { U.S. FDI } \\
1966\end{array}$ & $\begin{array}{c}R \& D \text { by } \\
\text { U.S. } \\
\text { Multinat. }\end{array}$ & $\begin{array}{c}\text { CPI } \\
\text { Inflation }\end{array}$ & IPR 1965 & $\begin{array}{c}\text { Exch. } \\
\text { Rate }\end{array}$ & OWTI & Constant \\
\hline Coefficient: & .000 & -.004 & .0003 & .019 & -.008 & -.061 & .055 \\
\hline T-Statistic: & 3.29 & -2.41 & 2.23 & 1.90 & -2.67 & -1.78 & 1.73 \\
\hline
\end{tabular}




\section{Dependent Variable: Population}

OLS Regression

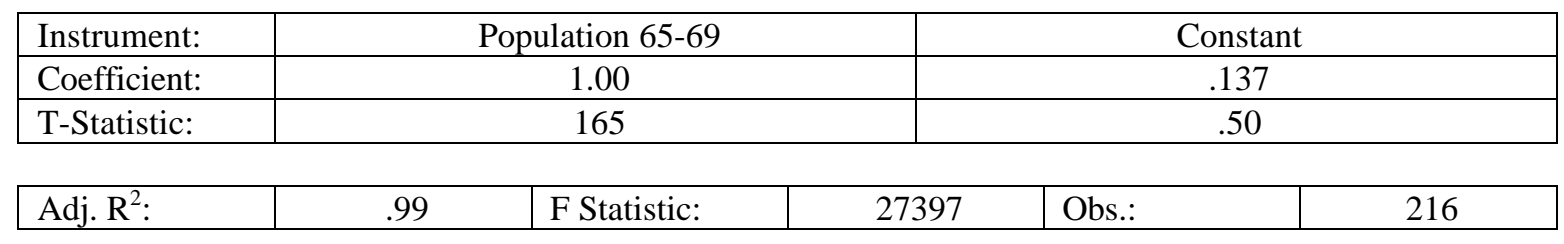

\section{Correlation across Explanatory Variables in Imitation Regression}

\begin{tabular}{|c|c|c|c|c|c|c|c|c|}
\hline & POP & $I P R$ & $F D I S H$ & HIMSH & RIMSH & JAPAN & SKILL & RTPC \\
\hline POP & 1 & & & & & & & \\
\hline$I P R$ & -.10 & 1 & & & & & & \\
\hline FDISH & .08 & -.23 & 1 & & & & & \\
\hline HIMSH & .78 & -.38 & .09 & 1 & & & & \\
\hline RIMSH & .11 & -.02 & -.31 & -.21 & 1 & & & \\
\hline JAPAN & .72 & -.31 & .27 & .85 & -.29 & 1 & & \\
\hline SKILL & -.73 & -.45 & .04 & -.43 & .01 & -.59 & 1 & \\
\hline RTPC & .01 & -.23 & .21 & .10 & -.69 & .32 & -.01 & 1 \\
\hline CONS & .29 & -.19 & -.19 & .54 & .36 & .31 & -.15 & -.69 \\
\hline
\end{tabular}

Correlation across Explanatory Variables in Innovation Regression

\begin{tabular}{|c|c|c|c|c|c|c|c|c|}
\hline & POP & $I P R$ & $F D I S H$ & HIMSH & RIMSH & SKILL & RTPC & CONS \\
\hline POP & 1 & & & & & & & \\
\hline$I P R$ & -.12 & 1 & & & & & & \\
\hline FDISH & -.43 & .42 & 1 & & & & & \\
\hline HIMSH & .66 & -.33 & -.66 & 1 & & & & \\
\hline RIMSH & .53 & -.12 & -.29 & .06 & 1 & & & \\
\hline SKILL & -.48 & -.62 & .03 & -.07 & -.38 & 1 & & \\
\hline RTPC & -.23 & -.36 & .17 & -.03 & -.70 & .52 & 1 & \\
\hline CONS & .18 & .07 & -.49 & .38 & .51 & -.35 & -.84 & 1 \\
\hline
\end{tabular}




\section{Technical Notes:}

Used avg of 3 yrs trade data to make endpoints for 5 yr periods so single year fluctuations didn't yield odd observations 
Several recent empirical papers have considered the role that trade may take in the international diffusion of technology. Eaton and Kortum (1995) consider geographical distance, human capital, and the level of a country's imports from a partner country relative to its own GNP as factors that could influence technological diffusion between the partner country and the home country. Using patent data from 19 OECD countries, they find that imports are significant in explaining technological diffusion, but that the elasticity for that variable is very small (approximately 0.1). However, according to Eaton and Kortum, geographical distance and human capital play a larger role in technological diffusion. So while they conclude that ideas are mobile internationally, driving much of the world's productivity growth, they do not find a strong link to international trade. However, since they are only considering technological diffusion between developed nations, these results may underestimate the role that trade may play in the diffusion of technology between developed and less developed countries. Another interesting finding from the Eaton and Kortum paper is that with the exception of the United States, countries in the Organization for Economic Cooperation and Development (OECD) derive almost all of their productivity growth from abroad. This rather surprising result is confirmed in the study presented here.

Coe and Helpman (1993) consider the importance of the role played by the domestic $R \& D$ capital stock as well as the import weighted sum of $R \& D$ stocks of a country's trade partners in domestic total factor productivity growth. Using a sample of twenty-two developed countries, Coe and Helpman find that both the domestic and the foreign $R \& D$ capital stocks (measured as accumulated $R \& D$ expenditures) have significant effects on a country's total factor productivity, and that the effect of the foreign $R \& D$ stocks is greater the more open the economy. Coe, Helpman, and Hoffmaister (1995) extend this type of analysis to 77 developing countries although only foreign $R \& D$ stocks are considered. They find that the total factor productivity of developing nations increases with a greater import weighted foreign (DC) $R \& D$ capital stock, increased openness to trade with developed nations, and greater secondary school enrollment.

However, the work of Keller (1997) raises serious questions about the interpretation of Coe and Helpman style results and methodology, since Keller also estimates large international $R \& D$ spillover effects using randomly generated bilateral trade shares instead of actual bilateral trade shares. Again, this may in part be the result of the fact that only developed and relatively highly interactive countries are being considered. Keller's results may be interpreted as suggesting that one should not focus narrowly on bilateral trade shares if the group of countries has a great deal of general interaction amongst themselves. ${ }^{37}$ However, I would argue that for developing nations (which are

37 For example, suppose one country, say France, interacts a great deal with a second country, say Germany, thus allowing technology transfers between France and Germany to occur easily through mechanisms other than goods trade. Then France would benefit not only from the technology embodied in its own imports from the rest of the world, but also from any technology that Germany gains from its imports from the rest of the world. Hence, France could benefit from $R \& D$ efforts in third countries without particularly having to trade directly with those countries so long as Germany (or other countries with which France is highly integrated) is trading with these other countries. 
generally not integrated with DCs), trade in physical goods will be a much more important channel through which these countries can gain access to more advanced technology.

Still, Ben-David (1996) finds that trade-based country groupings are more likely to converge than randomly selected country groupings. Ben-David and Rahman (1996) build upon this result by suggesting that convergence in trade-based country groupings can be attributed to convergence in technologies. This is demonstrated by a high incidence of total factor productivity convergence among trade-based country groups, whereas no such technological convergence is found among randomly selected country groupings. Thus trade appears to play an important role in technological diffusion and, in turn, conditional convergence.

Relative to the existing literature on trade and technological diffusion, this paper attempts to see specifically what direct effect trade has on domestic innovation and imitation, and in turn, what effect domestic and foreign innovation have on real per capita GDP growth. Specifically, this study is one of the first papers to attempt to quantify imitative activity across both DCs and LDCs. 


\section{Table 2B. Pooled 2SLS Growth Regressions}

(using White's Heteroskedasticity Correction)

Dependent Variable: Growth of Real GDP Per Capita $(Y)$

\begin{tabular}{|c|c|c|c|c|}
\hline & $\begin{array}{l}\text { (1) } \\
\text { G7 }\end{array}$ & $\begin{array}{c}\text { (2) } \\
\text { Non-G7 }\end{array}$ & $\begin{array}{c}\text { (3) } \\
\text { DCs }\end{array}$ & $\begin{array}{c}\text { (4) } \\
\text { LDCs }\end{array}$ \\
\hline Constant & $\begin{array}{c}.248 * * * \\
(2.39)\end{array}$ & $\begin{array}{l}.091 * * * * \\
(3.07)\end{array}$ & $\begin{array}{l}.084 * * \\
(1.91)\end{array}$ & $\begin{array}{c}.127 * * * * \\
(3.67)\end{array}$ \\
\hline $\begin{array}{l}\text { 1965-69 GDP per } \\
\text { capita }\left(Y_{t-1}\right)\end{array}$ & $\begin{array}{c}-.025 * * * \\
(-2.08)\end{array}$ & $\begin{array}{c}-.011 * * * * \\
(-2.81)\end{array}$ & $\begin{array}{l}-.007 \\
(-1.42)\end{array}$ & $\begin{array}{c}-.017 * * * * \\
(-3.49)\end{array}$ \\
\hline $\begin{array}{l}\text { Growth of per capita } \\
\text { Capital Stock }(K)\end{array}$ & $\begin{array}{l}-.151^{*} \\
(-1.58)\end{array}$ & $\begin{array}{c}.338 * * * * \\
(3.92)\end{array}$ & $\begin{array}{l}.042 \\
(.604)\end{array}$ & $\begin{array}{c}.355^{* * * * *} \\
(3.80)\end{array}$ \\
\hline $\begin{array}{l}\text { Growth of per capita } \\
\text { High Tech. Imports }(H)\end{array}$ & $\begin{array}{c}.073 * * * \\
(2.73)\end{array}$ & $\begin{array}{c}.102 * * * * \\
(3.87)\end{array}$ & $\begin{array}{c}.053 * * * * \\
(3.09)\end{array}$ & $\begin{array}{c}.131 * * * * \\
(4.33)\end{array}$ \\
\hline Domestic Innovation $(I)$ & $\begin{array}{l}.0002 \\
(.103)\end{array}$ & $\begin{array}{l}.003 * * * \\
(2.16)\end{array}$ & $\begin{array}{l}-.001 \\
(-.925)\end{array}$ & $\begin{array}{l}.004 * * \\
(1.65)\end{array}$ \\
\hline $\begin{array}{l}\text { Observations } \\
R^{2}\end{array}$ & $\begin{array}{l}21 \\
.43 \\
\end{array}$ & $\begin{array}{l}90 \\
.57 \\
\end{array}$ & $\begin{array}{l}51 \\
.31 \\
\end{array}$ & $\begin{array}{l}60 \\
.66 \\
\end{array}$ \\
\hline
\end{tabular}

$* * * *$ Significant at the $1 \%$ confidence level. $* * * 5 \%$ conf. level. $* * 10 \%$ conf. level. $* 15 \%$ conf. level. All variables are in natural logarithms. $\quad \mathrm{t}$-statistics are in parentheses.

Table 1. Innovation and Imitation Regressions (using White's Heteroskedasticity Correction)

Dependent Variable

Constant

\begin{tabular}{|c|c|c|c|}
\hline \multicolumn{2}{|c|}{$\begin{array}{c}\text { Imitation } \mathbf{R} \\
\text { Eq. } 1\end{array}$} & \multicolumn{2}{|c|}{$\begin{array}{c}\text { Innovation } \mathbf{R} \\
\text { Eq. } 2\end{array}$} \\
\hline (1) & (2) & (3) & (4) \\
\hline $\begin{array}{c}\text { Cross - Section } \\
\text { (Between) } \\
2 S L S\end{array}$ & $\begin{array}{c}\text { Random Effects } \\
2 S L S \\
(\theta=0) \Rightarrow \text { same as } \\
\text { Pooled } 2 S L S\end{array}$ & $\begin{array}{c}\text { Cross - Section } \\
\text { (Between) } \\
2 S L S\end{array}$ & $\begin{array}{c}\text { Random Effects } \\
2 S L S \\
(\theta=0) \\
\Rightarrow \text { same as Pooled } \\
2 S L S\end{array}$ \\
\hline $\begin{array}{c}-13.8 * * * * \\
(-6.52)\end{array}$ & $\begin{array}{c}-8.97 * * * \\
(-2.54)\end{array}$ & $\begin{array}{l}-8.35 \\
(-1.50)\end{array}$ & $\begin{array}{c}-6.03 \\
(-1.38)\end{array}$ \\
\hline
\end{tabular}




\begin{tabular}{|c|c|c|c|c|}
\hline $\begin{array}{l}\text { Quality Adj. Research } \\
\text { Effort }(R)\end{array}$ & $\begin{array}{c}1.61 * * * * \\
(6.15)\end{array}$ & $\begin{array}{c}1.02 * * * * \\
(4.49)\end{array}$ & $\begin{array}{l}1.16^{* * * * *} \\
(6.20)\end{array}$ & $\begin{array}{c}.861 * * * * \\
(4.31)\end{array}$ \\
\hline $\begin{array}{l}\text { Transp. \& Communic. } \\
\text { Infrastructure }(F)\end{array}$ & $\begin{array}{l}1.72 * * * * \\
(5.14)\end{array}$ & $\begin{array}{l}1.59 * * * * \\
(4.35)\end{array}$ & $\begin{array}{c}.902 \\
(1.59)\end{array}$ & $\begin{array}{l}.404 \\
(.853)\end{array}$ \\
\hline $\begin{array}{l}\text { High Tech. Imports as } \\
\text { Share of GDP }(H)\end{array}$ & $\begin{array}{l}.555 \\
(1.19)\end{array}$ & $\begin{array}{c}1.41 * * * * \\
(3.05)\end{array}$ & $\begin{array}{c}1.34 * * * * \\
(4.69)\end{array}$ & $\begin{array}{c}1.27 * * * * \\
(3.17)\end{array}$ \\
\hline $\begin{array}{l}\text { Non-High Tech. } \\
\text { Imports as Share of } \\
\text { GDP }(\mathrm{NH})\end{array}$ & $\begin{array}{c}-1.37 * * * * \\
(-3.34)\end{array}$ & $\begin{array}{c}-1.29 * * * * \\
(-3.79)\end{array}$ & $\begin{array}{l}-.731 \\
(-1.18)\end{array}$ & $\begin{array}{l}-.163 \\
(-.424)\end{array}$ \\
\hline $\begin{array}{l}\text { Foreign Direct Invest. } \\
\text { as Share of GDP }(F D I)\end{array}$ & $\begin{array}{l}-3.38 \\
(-.915)\end{array}$ & $\begin{array}{l}-3.19 \\
(-.745)\end{array}$ & $\begin{array}{c}-7.48^{* *} \\
(-2.06)\end{array}$ & $\begin{array}{l}-2.80 \\
(-.823)\end{array}$ \\
\hline Population (POP) & $\begin{array}{l}.066 \\
(.246)\end{array}$ & $\begin{array}{c}.736 * * * \\
(2.24)\end{array}$ & $\begin{array}{l}.546 \\
(1.51)\end{array}$ & $\begin{array}{l}.890 * * * * \\
(2.64)\end{array}$ \\
\hline $\begin{array}{l}\text { Intellectual Property } \\
\text { Rights }(P)\end{array}$ & $\begin{array}{c}-.948 * * * \\
(-2.62)\end{array}$ & $\begin{array}{l}-.706 * * \\
(-1.77)\end{array}$ & $\begin{array}{c}.639 \\
(1.08)\end{array}$ & $\begin{array}{l}.694^{*} \\
(1.64)\end{array}$ \\
\hline Japan Dummy & $\begin{array}{l}.699 \\
(.574)\end{array}$ & $\begin{array}{l}2.95 * * * * \\
(3.01)\end{array}$ & & \\
\hline $\begin{array}{l}\text { Observations } \\
R^{2} \\
\text { F-Statistic }\end{array}$ & $\begin{array}{l}17 \\
.96 \\
9.9 \\
\end{array}$ & $\begin{array}{l}39 \\
.86 \\
88 \\
\end{array}$ & $\begin{array}{l}15 \\
.94 \\
44 \\
\end{array}$ & $\begin{array}{l}35 \\
.84 \\
28 \\
\end{array}$ \\
\hline
\end{tabular}

$* * * *$ Significant at the $1 \%$ confidence level. $* * * 5 \%$ conf. level. $* * 10 \%$ conf. level. $* 15 \%$ conf. level. All variables are in natural logarithms. $\quad$ t-statistics are in parentheses. 
Table A1. Innovation and Imitation Regressions

(using White's Heteroskedasticity Correction)

\section{Dependent Variable}

Constant
Quality Adj. Research
Effort (R)

Transp. \& Communic. Infrastructure $(F)$

High Tech. Import Levels $(H)$

Non-High Tech. Import Levels (NH)

Real GDP (GDP)

Intellectual Property Rights (P)

Observations

$\boldsymbol{R}^{2}$

F-Statistic

\begin{tabular}{|c|c|c|c|c|c|}
\hline \multicolumn{3}{|c|}{$\begin{array}{c}\text { Imitation } \\
\text { Eq. } 1\end{array}$} & \multicolumn{3}{|c|}{$\begin{array}{c}\text { Innovation } \\
\text { Eq. } 2\end{array}$} \\
\hline (1) & (2) & (3) & (4) & (5) & (6) \\
\hline $\begin{array}{c}\text { Pooled } \\
2 S L S\end{array}$ & $\begin{array}{c}\text { Cross - } \\
\text { Section } \\
\text { (Between) } \\
2 S L S\end{array}$ & $\begin{array}{c}\text { Random } \\
\text { Effects } \\
2 S L S\end{array}$ & $\begin{array}{c}\text { Pooled } \\
2 S L S\end{array}$ & $\begin{array}{c}\text { Cross - } \\
\text { Section } \\
\text { (Between) } \\
2 S L S\end{array}$ & $\begin{array}{c}\text { Random } \\
\text { Effects } \\
2 S L S\end{array}$ \\
\hline $\begin{array}{l}-11.6^{*} \\
(-4.21)\end{array}$ & $\begin{array}{l}-8.75^{* *} \\
(-2.29)\end{array}$ & $\begin{array}{l}-2.09 * * \\
(-2.01)\end{array}$ & $\begin{array}{l}-18.3^{*} \\
(-7.44)\end{array}$ & $\begin{array}{l}-17.7 * \\
(-3.22)\end{array}$ & $\begin{array}{l}-18.3 * \\
(-7.44)\end{array}$ \\
\hline $\begin{array}{c}.178 \\
(1.19)\end{array}$ & $\begin{array}{c}.341 \\
(1.46)\end{array}$ & $\begin{array}{l}-.525^{*} \\
(-2.73)\end{array}$ & $\begin{array}{l}.154 * * \\
(1.74)\end{array}$ & $\begin{array}{l}.323 * * \\
(2.71)\end{array}$ & $\begin{array}{l}.154 * * \\
(1.74)\end{array}$ \\
\hline $\begin{array}{l}.432 * * \\
(2.11)\end{array}$ & $\begin{array}{c}.329 \\
(1.48)\end{array}$ & $\begin{array}{c}.080 \\
(.132)\end{array}$ & $\begin{array}{l}.943 * \\
(6.44)\end{array}$ & $\begin{array}{l}1.06 * * \\
(2.71)\end{array}$ & $\begin{array}{l}.943 * \\
(6.44)\end{array}$ \\
\hline $\begin{array}{l}.983 * * \\
(2.09)\end{array}$ & $\begin{array}{c}1.22 * * * \\
(2.04)\end{array}$ & $\begin{array}{l}1.76^{*} \\
(3.05)\end{array}$ & $\begin{array}{l}2.13 * \\
(6.87)\end{array}$ & $\begin{array}{c}2.0 * \\
(4.74)\end{array}$ & $\begin{array}{l}2.13 * \\
(6.87)\end{array}$ \\
\hline $\begin{array}{l}-.992 * \\
(-3.48)\end{array}$ & $\begin{array}{l}-1.02 * \\
(-2.99)\end{array}$ & $\begin{array}{c}-.988 \\
(-1.14)\end{array}$ & $\begin{array}{l}-1.26^{*} \\
(-6.78)\end{array}$ & $\begin{array}{l}-1.33^{*} \\
(-4.40)\end{array}$ & $\begin{array}{l}-1.26^{*} \\
(-6.78)\end{array}$ \\
\hline $\begin{array}{l}.995^{*} \\
(3.78)\end{array}$ & $\begin{array}{l}.712 * * \\
(2.05)\end{array}$ & $\begin{array}{c}.956 * * * \\
(1.56)\end{array}$ & $\begin{array}{l}.578 * \\
(3.14)\end{array}$ & $\begin{array}{c}.559 \\
(1.49)\end{array}$ & $\begin{array}{l}.578^{*} \\
(3.14)\end{array}$ \\
\hline $\begin{array}{l}.606^{*} \\
(2.58)\end{array}$ & $\begin{array}{c}.521 * * * * \\
(1.53)\end{array}$ & $\begin{array}{c}.465 \\
(1.56)\end{array}$ & $\begin{array}{l}.835^{*} \\
(3.84)\end{array}$ & $\begin{array}{l}.930 * \\
(3.53)\end{array}$ & $\begin{array}{l}.835^{*} \\
(3.84)\end{array}$ \\
\hline $\begin{array}{l}81 \\
.80 \\
57\end{array}$ & $\begin{array}{l}25 \\
.85 \\
32\end{array}$ & $\begin{array}{l}75 \\
\dot{6}\end{array}$ & $\begin{array}{l}55 \\
.89 \\
88\end{array}$ & $\begin{array}{c}18 \\
.95 \\
185\end{array}$ & $\begin{array}{l}55 \\
.89 \\
88\end{array}$ \\
\hline
\end{tabular}

*Significant at the $1 \%$ confidence level. $\quad * * 5 \%$ conf. level. $* * * 10 \%$ conf. level. $* * * * 15 \%$ conf. level. All variables are in natural logarithms. $\quad$ t-statistics are in parentheses. 
Table A2. Growth Regressions

Eq. (3') (using White's Heteroskedasticity Correction)

Dependent Variable: Growth of Real GDP Per Capita $(Y)$

\begin{tabular}{|c|c|c|c|}
\hline & $\begin{array}{c}(1) \\
\text { Pooled } 2 S L S\end{array}$ & $\begin{array}{c}(2) \\
\text { Cross-Section } \\
\text { (Between) } \\
2 S L S \\
\end{array}$ & $\begin{array}{c}(3) \\
\text { Random Effects } \\
2 S L S\end{array}$ \\
\hline Constant & $\begin{array}{l}.071 * \\
(2.50)\end{array}$ & $\begin{array}{c}.071 * * * \\
(1.53)\end{array}$ & $\begin{array}{l}.082 * * \\
(2.19)\end{array}$ \\
\hline $\begin{array}{l}\text { 1965-69 GDP per } \\
\text { capita }\left(Y_{t-1}\right)\end{array}$ & $\begin{array}{l}-.009 * * \\
(-2.27)\end{array}$ & $\begin{array}{c}-.009 * * * \\
(-1.47)\end{array}$ & $\begin{array}{l}-.012 * * \\
(-1.98)\end{array}$ \\
\hline $\begin{array}{l}\text { Growth of per capita } \\
\text { Capital Stock }(K)\end{array}$ & $\begin{array}{l}.327 * \\
(3.70)\end{array}$ & $\begin{array}{l}.424^{*} \\
(2.87)\end{array}$ & $\begin{array}{l}.231 * * \\
(1.98)\end{array}$ \\
\hline $\begin{array}{l}\text { Growth of Level of High } \\
\text { Tech. Imports }(H)\end{array}$ & $\begin{array}{l}.088^{*} \\
(3.59)\end{array}$ & $\begin{array}{l}.134 * * \\
(1.72)\end{array}$ & $\begin{array}{l}.108^{*} \\
(3.91)\end{array}$ \\
\hline Domestic Innovation $(I)$ & $\begin{array}{l}.002 * * * \\
(1.87)\end{array}$ & $\begin{array}{l}.002 \\
(.961)\end{array}$ & $\begin{array}{c}.003 * * * * \\
(1.55)\end{array}$ \\
\hline $\begin{array}{l}\text { Observations } \\
R^{2}\end{array}$ & $\begin{array}{l}107 \\
.51\end{array}$ & $\begin{array}{l}32 \\
.63\end{array}$ & $\begin{array}{l}96 \\
.49\end{array}$ \\
\hline
\end{tabular}

$*$ Significant at the $1 \%$ confidence level. $* * 5 \%$ conf. level. ***10\% conf. level. ****15\% conf. level. All variables are in natural logarithms. $\quad$ t-statistics are in parentheses. 


\section{Table A2. Innovation and Imitation Regressions when Considering Imports Per Capita}

$$
\text { (using White's Heteroskedasticity Correction) }
$$

\section{Dependent Variable}

Constant
Quality Adj. Research
Effort (R)

Transp. \& Communic. Infrastructure $(F)$

High Tech. Imports Per Capita (HPC)

Non-High Tech. Imports Per Capita (NHPC)

Real GDP (GDP)

Intellectual Property Rights (P)

Observations

$R^{2}$

F-Statistic

\begin{tabular}{|c|c|c|c|c|c|}
\hline \multicolumn{3}{|c|}{$\begin{array}{c}\text { Imitation } \\
\text { Eq. } 1\end{array}$} & \multicolumn{3}{|c|}{$\begin{array}{c}\text { Innovation } \\
\text { Eq. } 2\end{array}$} \\
\hline $\begin{array}{l}(1) \\
\text { Pooled } \\
2 S L S\end{array}$ & $\begin{array}{c}(2) \\
\text { Cross - } \\
\text { Section } \\
\text { (Between) } \\
2 S L S\end{array}$ & $\begin{array}{c}(3) \\
\text { Random } \\
\text { Effects } \\
2 S L S \\
\\
-3.53^{* *} \\
(-2.15) \\
\\
-.266^{* *} \\
(-2.05) \\
\\
-.177 \\
(-.445) \\
\\
1.71^{*} \\
(3.97) \\
\\
-1.11^{* *} \\
(-2.35)\end{array}$ & $\begin{array}{l}(4) \\
\text { Pooled } \\
2 S L S\end{array}$ & $\begin{array}{c}(5) \\
\text { Cross - } \\
\text { Section } \\
\text { (Between) } \\
2 S L S\end{array}$ & $\begin{array}{c}(6) \\
\text { Random } \\
\text { Effects } \\
2 S L S\end{array}$ \\
\hline & & $\begin{array}{c}1.42 * \\
(6.52) \\
.515^{* * *} \\
(1.55)\end{array}$ & & & \\
\hline $\begin{array}{l}81 \\
.80 \\
57\end{array}$ & $\begin{array}{l}25 \\
.85 \\
32\end{array}$ & $\begin{array}{l}75 \\
.61 \\
19\end{array}$ & $\begin{array}{l}55 \\
.89 \\
88\end{array}$ & $\begin{array}{l}18 \\
.95 \\
185\end{array}$ & $\begin{array}{l}55 \\
.89 \\
88\end{array}$ \\
\hline
\end{tabular}

$*$ Significant at the $1 \%$ confidence level. $* * 5 \%$ conf. level. $* * * 10 \%$ conf. level. $* * * * 15 \%$ conf. level. All variables are in natural logarithms. t-statistics are in parentheses. 


\section{Table A1. Cross Section - Instrumental Variables Estimation}

Dep. Var. :

Constant

Quality Adj. Research

Effort (R)

Transp. \& Communic.

Infrastructure $(F)$

Per Capita High Tech.

Imports (HPC)

Per Capita Non-High

Tech. Imports (NHPC)

High Tech. Imports as

share of GDP $(\mathrm{HSH})$

Non-High Tech.

Imports as share of

GDP (NHSH)

Real GDP (GDP)

Patent Protection (P)

Observations

Adjusted $R^{2}$

F-Statistic
Imitation

$-9.07$

(-1.61)

.377

(1.39)

.345

(1.17)

(.379)

$1.29 * * *$

$-.954 * * *$

$(-1.86)$

1.04

(.955)

$-.949 * * *$

(-1.67)

.944*

(3.19)

$.876 * * *$

(1.75)

1.27 *

(3.91)

$1.26^{*}$

(3.65)

$$
\begin{aligned}
& .10 \\
& (.30)
\end{aligned}
$$

.232

(.472)
$.527 * *$
(2.37)

$.569 * *$

$\begin{array}{ll}25 & 25 \\ .79 & .77 \\ 15 & 14\end{array}$

$\begin{array}{ll}18 & 18 \\ .93 & .93 \\ 37 & 37\end{array}$

* Significant at the $1 \%$ confidence level. All variables are in natural logarithms.

$* * 5 \%$ confidence level. $\quad * * * 10 \%$ confidence level. $\mathrm{t}$-statistics are in parentheses. 


\section{Additional Results}

Table 1. Innovation and Imitation Regressions (using White's Heteroskedasticity Correction)

\begin{tabular}{|c|c|c|c|c|c|c|}
\hline \multirow[t]{2}{*}{$\begin{array}{l}\text { Dependent } \\
\text { Variable }\end{array}$} & \multicolumn{3}{|c|}{$\begin{array}{c}\text { Imitation } \mathbf{R} \\
\text { Eq. } 1\end{array}$} & \multicolumn{3}{|c|}{$\begin{array}{c}\text { Innovation } \mathbf{R} \\
\text { Eq. } 2\end{array}$} \\
\hline & $\begin{array}{l}(1) \\
\text { Pooled } \\
2 S L S\end{array}$ & $\begin{array}{c}(2) \\
\text { Cross - } \\
\text { Section } \\
\text { (Between) } \\
\text { 2SLS }\end{array}$ & $\begin{array}{c}(3) \\
\text { Random } \\
\text { Effects } \\
2 S L S \\
(\theta=0)\end{array}$ & $\begin{array}{l}\text { (4) } \\
\text { Pooled } \\
2 S L S\end{array}$ & $\begin{array}{c}(5) \\
\text { Cross - } \\
\text { Section } \\
\text { (Between) } \\
2 S L S\end{array}$ & $\begin{array}{c}(6) \\
\text { Random } \\
\text { Effects } \\
2 S L S \\
(\theta=0)\end{array}$ \\
\hline Constant & $\begin{array}{c}-23.9 * * * * \\
(-6.70)\end{array}$ & $\begin{array}{l}-26.76 * * * * \\
(-12.4)\end{array}$ & $\begin{array}{l}-23.9 * * * * \\
(-6.70)\end{array}$ & $\begin{array}{l}-18.45 * * * * \\
\quad(-4.44)\end{array}$ & $\begin{array}{c}-20.6 * * * * \\
(-3.70)\end{array}$ & $\begin{array}{c}-18.45 * * * * \\
\quad(-4.44)\end{array}$ \\
\hline $\begin{array}{l}\text { Quality Adj. Research } \\
\text { Effort }(R)\end{array}$ & $\begin{array}{c}1.47 * * * * \\
(6.82)\end{array}$ & $\begin{array}{c}1.74 * * * * \\
(19.0)\end{array}$ & $\begin{array}{c}1.47 * * * * \\
(6.82)\end{array}$ & $\begin{array}{l}.884 * * * * \\
(4.58)\end{array}$ & $\begin{array}{c}1.16 * * * * \\
(6.20)\end{array}$ & $\begin{array}{c}.884 * * * * \\
(4.58)\end{array}$ \\
\hline $\begin{array}{l}\text { Transp. \& Communic. } \\
\text { Infrastructure }(F)\end{array}$ & $\begin{array}{c}1.38 * * * * \\
(3.74)\end{array}$ & $\begin{array}{c}1.67 * * * * \\
(6.50)\end{array}$ & $\begin{array}{c}1.38 * * * * \\
(3.74)\end{array}$ & $\begin{array}{l}.438 \\
(.968)\end{array}$ & $\begin{array}{l}.902 \\
(1.59)\end{array}$ & $\begin{array}{l}.438 \\
(.968)\end{array}$ \\
\hline $\begin{array}{l}\text { High Tech. Imports as } \\
\text { Share of GDP }(H)\end{array}$ & $\begin{array}{l}.511^{*} \\
(1.55)\end{array}$ & $\begin{array}{l}.329 \\
(1.40)\end{array}$ & $\begin{array}{l}.511^{*} \\
(1.55)\end{array}$ & $\begin{array}{c}1.27 * * * * \\
(3.37)\end{array}$ & $\begin{array}{c}1.34 * * * * \\
(4.69)\end{array}$ & $\begin{array}{c}1.27 * * * * \\
(3.37)\end{array}$ \\
\hline $\begin{array}{l}\text { Non-High Tech. } \\
\text { Imports as Share of } \\
\text { GDP }(\mathrm{NH})\end{array}$ & $\begin{array}{c}-1.03 * * * \\
(-2.44)\end{array}$ & $\begin{array}{c}-1.31 * * * * \\
(-3.94)\end{array}$ & $\begin{array}{c}-1.03 * * * \\
(-2.44)\end{array}$ & $\begin{array}{l}-.195 \\
(-.525)\end{array}$ & $\begin{array}{l}-.731 \\
(-1.18)\end{array}$ & $\begin{array}{l}-.195 \\
(-.525)\end{array}$ \\
\hline $\begin{array}{l}\text { Foreign Direct Invest. } \\
\text { as Share of GDP (FDI) }\end{array}$ & $\begin{array}{l}-6.21^{*} \\
(-1.58)\end{array}$ & $\begin{array}{l}-3.81 \\
(-1.25)\end{array}$ & $\begin{array}{l}-6.21 * \\
(-1.58)\end{array}$ & $\begin{array}{l}-3.02 \\
(-.919)\end{array}$ & $\begin{array}{l}-7.48 * * \\
(-2.06)\end{array}$ & $\begin{array}{l}-3.02 \\
(-.919)\end{array}$ \\
\hline Population $(P O P)$ & $\begin{array}{l}.162 \\
(.655)\end{array}$ & $\begin{array}{l}-.082 \\
(-.40)\end{array}$ & $\begin{array}{l}.162 \\
(.655)\end{array}$ & $\begin{array}{c}.871 * * * * \\
(2.68)\end{array}$ & $\begin{array}{l}.546 \\
(1.51)\end{array}$ & $\begin{array}{c}.871 * * * * \\
(2.68)\end{array}$ \\
\hline $\begin{array}{l}\text { Intellectual Property } \\
\text { Rights }(P)\end{array}$ & $\begin{array}{l}-.755^{* *} \\
(-1.79)\end{array}$ & $\begin{array}{l}-.98 * * * \\
(-2.98)\end{array}$ & $\begin{array}{l}-.755^{* *} \\
(-1.79)\end{array}$ & $\begin{array}{l}.684^{*} \\
(1.66)\end{array}$ & $\begin{array}{l}.639 \\
(1.08)\end{array}$ & $\begin{array}{l}.684^{*} \\
(1.66)\end{array}$ \\
\hline $\begin{array}{l}\text { Observations } \\
R^{2} \\
\text { F-Statistic }\end{array}$ & $\begin{array}{l}39 \\
.85 \\
50\end{array}$ & $\begin{array}{l}17 \\
.95 \\
186\end{array}$ & $\begin{array}{l}39 \\
.85 \\
50\end{array}$ & $\begin{array}{l}35 \\
.85 \\
32\end{array}$ & $\begin{array}{l}15 \\
.94 \\
44\end{array}$ & $\begin{array}{l}35 \\
.85 \\
32\end{array}$ \\
\hline
\end{tabular}

$* * * *$ Significant at the $1 \%$ confidence level. $* * * 5 \%$ conf. level. $* * 10 \%$ conf. level. $* 15 \%$ conf. level.

All variables are in natural logarithms. $\quad$ t-statistics are in parentheses.

Table 2.

Instrumental Variables Estimation

Dependent Variable: Growth of Real GDP Per Capita $(Y)$

Using Determinants of Dom. Innov. 
Eq. 4

Pooled $O L S$

Constant

1965-69 GDP per

capita $\left(\mathbf{Y}_{\mathrm{t}-1}\right)$

Growth of per capita

Capital Stock (K)

Growth of High Tech.

Imports $(H)$

Per capita

Infrastructure $(F)$

Quality-Adjusted

Research Effort (R)

High Tech. Imports (H)

Patent Protection (P)

Observations

Adjusted R

F-Statistic
(1)

(2)

Cross -Section $O L S$

$.715^{\mathrm{a}}$

(2.89)

(1.29)

$-.009^{\mathrm{c}}$

$(-1.80)$

$.219^{\mathrm{a}}$

(3.31)

$.135^{\mathrm{a}}$

(9.02)

.004

(1.11)

$-.001$

$(-.516)$

.002

(1.01)

.002

(1.07)

144

.51

22 $.816^{\mathrm{a}}$

$4.85^{\mathrm{a}}$

(4.38)

$1.06^{\mathrm{b}}$

(2.05)

$.094^{\mathrm{b}}$

(2.08)

$-.006$

$(-.39)$

.025

(.917)

.014

(.698)

\section{0}

.98

310
(3)

Cross -Section

IV

$.080^{\mathrm{a}}$

(3.26)

$-.024^{\mathrm{a}}$

$(-4.18)$

$.336^{\mathrm{a}}$

(2.65)

$.128^{\mathrm{d}}$

(1.64)

$.009^{b}$

(2.06)

.0003

(.135)

.004

(1.06)

$.004^{\mathrm{d}}$

(1.50)

33

.72

13

aSignificant at the $1 \%$ confidence level. $\quad b_{5} \%$ conf. level. $\quad c_{10 \%}$ conf. level. $\quad d_{15 \%}$ conf. level. All variables are in natural logarithms.

$\mathrm{T}$-statistics are in parentheses.

I am particularly interested in considering how various factors such as imports of high technology goods, transportation and communications infrastructure, $R \& D$ efforts, and intellectual property right protection affect domestic innovation and imitation, thus indirectly affecting domestic growth. For this reason I first attempted to find reasonable proxies for innovation and imitation and tested the relationship between these proxies and the aforementioned factors. Another method by which I can attempt to see how these factors affect per capita GDP growth is to consider them directly in the growth regression. 
Hence, I again estimate the growth regression, only in lieu of the domestic innovation proxy, I use what the previous regressions have suggested are its determinants. ${ }^{38}$

The results of running $O L S$ and between-groups estimation on equation (4) are presented in the last two columns of Table 2. In the $O L S$ regression presented in column 3 , growth of the per capita capital stock and growth of capital imports from developed nations continue to be significant as before. However, the determinants of domestic innovation used in its place do not fare any better than the innovation proxy had in the previous $O L S$ regression of column 1.

On the other hand, in the cross-sectional regression, shown in column 4, all of the estimated coefficients for the explanatory variables are significant at the 1 percent confidence level except for research effort which does not come in significantly. All of the coefficients have their expected signs. The elasticity of per capita GDP growth is again greatest first with respect to growth of the capital stock and then to growth of high technology imports from developed countries. However, this regression, which now includes the determinants of domestic innovation rather than the proxy for domestic innovation, does better in terms of overall significance and adjusted $\mathrm{R}^{2}$, than the previous between-groups regression which used the domestic innovation proxy. ${ }^{39}$

Random effects estimation uses the following transformation of equation (1)

(1 R.E.) $C_{i t}-\theta \bar{C}_{i}=(1-\theta) \beta_{0}+\beta_{1}\left(R_{i t}-\theta \bar{R}_{i}\right)+\beta_{2}\left(F_{i t}-\theta \bar{F}_{i}\right)+\beta_{3}\left(H_{i t}-\theta \bar{H}_{i}\right)+$

$$
\beta_{4}\left(N H_{i t}-\theta \overline{N H}_{i}\right)+\beta_{5}\left(G D P_{i t}-\theta \overline{G D P}_{i}\right)+\left[(1-\theta) \alpha_{i}+\left(\varepsilon_{i}-\theta \bar{\varepsilon}_{i}\right)\right] .
$$

The weight, $\theta$, used in the above transformation depends on $\sigma_{\alpha}$ and $\sigma_{\varepsilon},{ }^{40}$

Table A1.

\section{Random Effects - Instrumental Variables Estimation}

\footnotetext{
${ }^{38}$ It may seem odd that these level terms are now being used in a growth regression. As previously mentioned this is done since it is the level of these terms which affect innovation, which in turn affects the growth of the economy. However, these regressions were also completed using growth rates yielding qualitatively similar results, although growth of the per capita transportation and communication infrastructure stock is not significant, perhaps due to collinearity with growth in the physical capital stock.

39 Again, the random effects regression estimates resemble the between-groups estimates and are presented in Table A3 in the appendix.

${ }^{40}$ Specifically, $\theta=1-\frac{\sigma_{\varepsilon}}{\left(T \sigma_{\alpha}^{2}+\sigma_{\varepsilon}^{2}\right)^{1 / 2}}$, where $\mathrm{T}=$ number of time periods.
} 
Dependent Variable:

Constant

Quality Adj. Research Effort

(R)

Transp. \& Communic.

Infrastructure $(F)$

High Tech. Imports $(H)$

Non-High Tech. Imports (NH)

Real GDP (GDP)

Patent Protection (P)

Observations

Adjusted R ${ }^{2}$

F-Statistic

asignificant at the $1 \%$ confidence level b5\%

\section{Imitation Proxy $(C)$}

Eq. (1 R.E.)

$-7.0^{\mathrm{a}}$

$(-3.47)$

.036

(.238)

$.278^{\mathrm{d}}$

(1.54)

.757

(1.30)

$-1.07^{\mathrm{a}}$

$(-2.80)$

$1.30^{\mathrm{a}}$

(3.47)

$.587^{\mathrm{b}}$

(2.36)

75

.70

31
Innovation Proxy (I)

Eq. (2 R.E.)

$-4.61^{\mathrm{a}}$

.057

(.50)

$.914^{\mathrm{b}}$

(2.47)

$.801^{\mathrm{c}}$

(1.91)

$-1.69^{\mathrm{a}}$

$1.66^{\mathrm{a}}$

$1.22^{\mathrm{a}}$

$(8.31)$

54

.77

32

Note: all variables are in natural logarithms.

Table A3. Random Effects IV Estimation

Dependent Variable: Growth of Real GDP Per Capita ( $Y)$ using determinants of Dom. Innov. equation (4 R.E.)

\begin{tabular}{lc} 
Constant & $.0842^{\mathrm{a}}$ \\
& $(.0257)$ \\
1965-69 GDP per capita $\left(\mathbf{Y}_{\mathbf{t}-}\right.$ & $-.0253^{\mathrm{a}}$ \\
$\mathbf{1})$ & $(.0059)$ \\
Growth of per capita Capital & $.1408^{\mathrm{d}}$ \\
Stock $(\mathbf{K})$ & $(.0907)$ \\
Growth of High Tech. & $.1271^{\mathrm{a}}$ \\
Imports $(\boldsymbol{H})$ & $(.0246)$ \\
\hline Domestic Innovation $(\mathbf{I})$ & \\
\hline Per capita Infrastructure $(\boldsymbol{F})$ & $.0077^{\mathrm{c}}$ \\
& $(.0041)$ \\
Quality-Adjusted Research & -.0017 \\
Effort $(\mathbf{R})$ & $(.0020)$ \\
High Tech. Imports $(H)$ & $.0080^{\mathrm{b}}$ \\
\end{tabular}




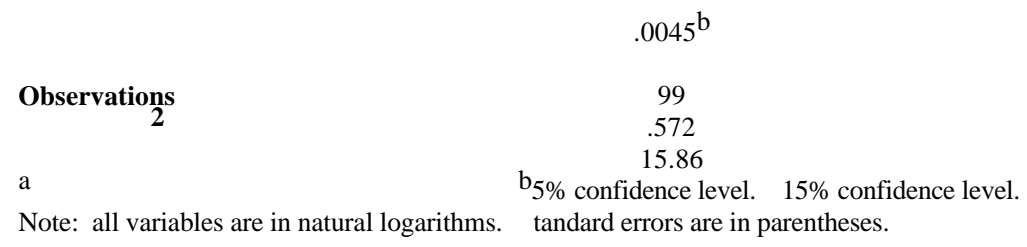

\section{Table 1.}

Variable

\begin{tabular}{|c|c|}
\hline Imitation & Innovation \\
& Eq. 2 \\
\hline
\end{tabular}

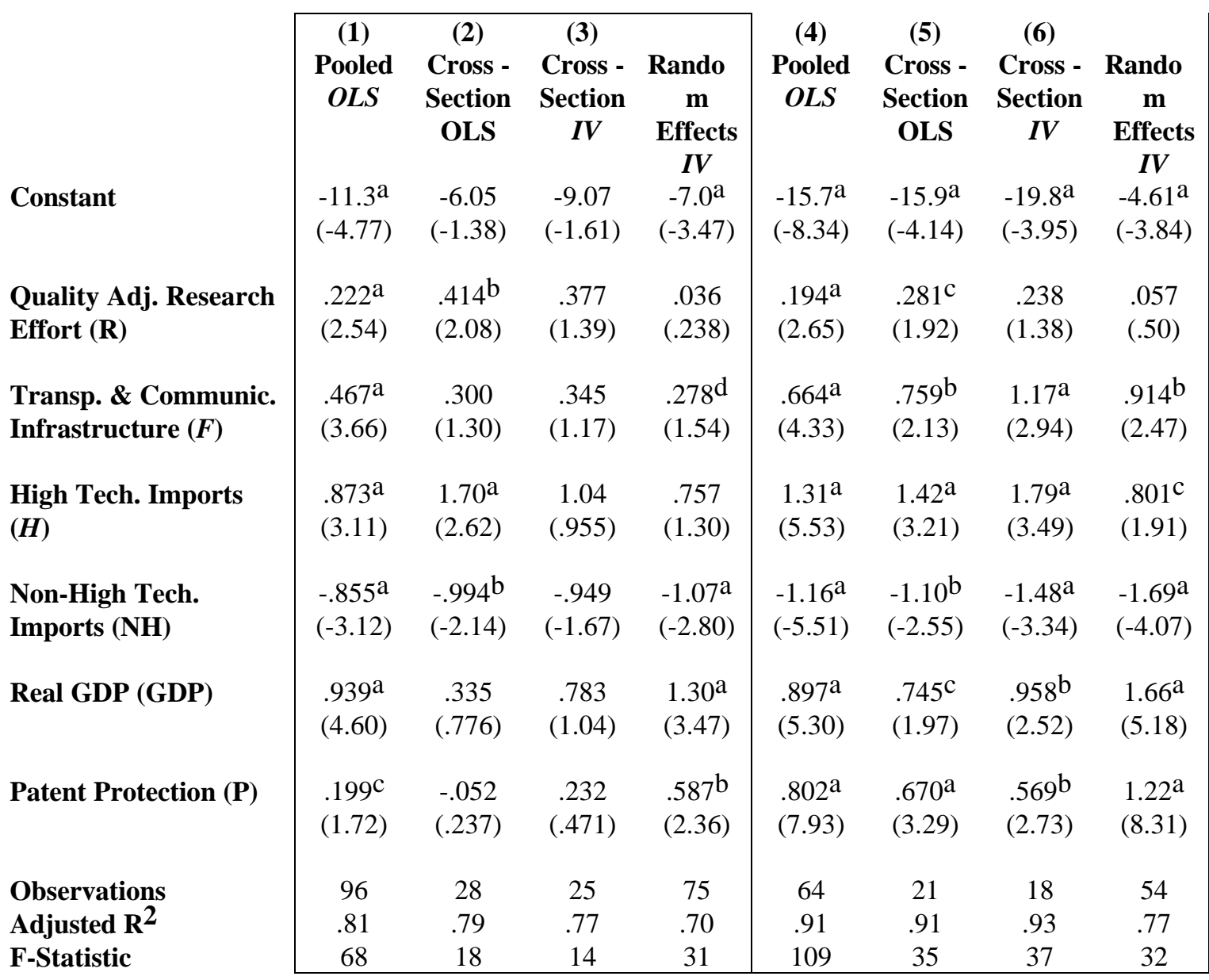

${ }^{a}$ Significant at the $1 \%$ confidence level. $\quad b_{5} \%$ confidence level. $c_{10 \%}$ confidence level. All variables are in natural logarithms. T-statistics are in parentheses.

Table 2.

Dependent Variable: Growth of Real GDP Per Capita $(Y)$

Eq. (3') 
(1)

Pooled OLS

\begin{tabular}{|c|c|c|c|}
\hline Constant & $\begin{array}{c}.014 \\
(.798)\end{array}$ & $\begin{array}{l}.037^{b} \\
(2.01)\end{array}$ & $\begin{array}{l}.071^{\mathrm{C}} \\
(1.95)\end{array}$ \\
\hline $\begin{array}{l}1965-69 \text { GDP per } \\
\text { capita }\left(Y_{t-1}\right)\end{array}$ & $\begin{array}{l}-.001 \\
(-.374)\end{array}$ & $\begin{array}{l}-.004^{c} \\
(-1.77)\end{array}$ & $\begin{array}{l}-.009 \\
(-1.90\end{array}$ \\
\hline $\begin{array}{l}\text { Growth of per capita } \\
\text { Capital Stock }(\mathbf{K})\end{array}$ & $\begin{array}{l}.268^{\mathrm{a}} \\
(5.86)\end{array}$ & $\begin{array}{l}.389^{a} \\
(5.76)\end{array}$ & $\begin{array}{l}.424^{\circ} \\
(3.51\end{array}$ \\
\hline $\begin{array}{l}\text { Growth of High Tech. } \\
\text { Imports }(H)\end{array}$ & $\begin{array}{l}.139^{\mathrm{a}} \\
(12.5)\end{array}$ & $\begin{array}{l}.180^{\mathrm{a}} \\
(5.35)\end{array}$ & $\begin{array}{l}.134^{1} \\
(4.07\end{array}$ \\
\hline Domestic Innovation (I) & $\begin{array}{l}-.0003 \\
(-.485)\end{array}$ & $\begin{array}{l}-.0001 \\
(-.151)\end{array}$ & $\begin{array}{r}.002 \\
(1.31\end{array}$ \\
\hline $\begin{array}{l}\text { Observations } \\
\text { Adjusted } \mathbf{R}^{2} \\
\text { F-Statistic }\end{array}$ & $\begin{array}{l}192 \\
.56 \\
63\end{array}$ & $\begin{array}{l}57 \\
.68 \\
31\end{array}$ & $\begin{array}{l}32 \\
.58 \\
11\end{array}$ \\
\hline
\end{tabular}

(2)
(3)

(4)

Cross -Section

OLS

Cross -Sect

IV

Random Effects

IV

$071^{\mathrm{c}}$

$.149^{\mathrm{a}}$

(3.16)

$-.010^{\mathrm{a}}$

$(-2.97)$

$.371^{\mathrm{a}}$

(4.73)

$134^{\mathrm{b}} \quad .097^{\mathrm{a}}$

4.07) (3.23)

$.002 \quad .002^{\mathrm{b}}$

(2.26)

$32 \quad 96$

$\begin{array}{ll}58 & .52\end{array}$

1120

From July 18 version:

Table 1.

\begin{tabular}{|c|c|c|c|c|c|c|}
\hline \multirow[t]{2}{*}{$\begin{array}{l}\text { Dependent } \\
\text { Variable }\end{array}$} & \multicolumn{3}{|c|}{$\begin{array}{l}\text { Imitation } \\
\text { Eq. } 1\end{array}$} & \multicolumn{3}{|c|}{$\begin{array}{c}\text { Innovation } \\
\text { Eq. } 2\end{array}$} \\
\hline & $\begin{array}{c}(1) \\
\text { Pooled } \\
\text { OLS } \\
\\
-11.3^{\mathrm{a}} \\
(-4.77)\end{array}$ & $\begin{array}{c}(2) \\
\text { Cross - } \\
\text { Section } \\
\boldsymbol{I V} \\
-9.07 \\
(-1.61)\end{array}$ & $\begin{array}{c}(3) \\
\text { Random } \\
\text { Effects } \\
\boldsymbol{I} \boldsymbol{V} \\
-7.0^{\mathrm{a}} \\
(-3.47)\end{array}$ & $\begin{array}{c}(4) \\
\text { Pooled } \\
\text { OLS } \\
\\
-15.7^{\mathrm{a}} \\
(-8.34)\end{array}$ & $\begin{array}{c}(\mathbf{5}) \\
\text { Cross - } \\
\text { Section } \\
\boldsymbol{I} \boldsymbol{V} \\
-19.8^{\mathrm{a}} \\
(-3.95)\end{array}$ & $\begin{array}{c}(\mathbf{6}) \\
\text { Random } \\
\text { Effects } \\
\boldsymbol{I} \boldsymbol{V} \\
-4.61^{\mathrm{a}} \\
(-3.84)\end{array}$ \\
\hline $\begin{array}{l}\text { Quality Adj. Research } \\
\text { Effort (R) }\end{array}$ & $\begin{array}{l}.222^{\mathrm{a}} \\
(2.54)\end{array}$ & $\begin{array}{c}.377 \\
(1.39)\end{array}$ & $\begin{array}{c}.036 \\
(.238)\end{array}$ & $\begin{array}{l}.194^{\mathrm{a}} \\
(2.65)\end{array}$ & $\begin{array}{c}.238 \\
(1.38)\end{array}$ & $\begin{array}{l}.057 \\
(.50)\end{array}$ \\
\hline $\begin{array}{l}\text { Transp. \& Communic. } \\
\text { Infrastructure }(F)\end{array}$ & $\begin{array}{l}.467^{\mathrm{a}} \\
(3.66)\end{array}$ & $\begin{array}{l}.345 \\
(1.17)\end{array}$ & $\begin{array}{l}.278^{\mathrm{d}} \\
(1.54)\end{array}$ & $\begin{array}{l}.664^{\mathrm{a}} \\
(4.33)\end{array}$ & $\begin{array}{l}1.17^{\mathrm{a}} \\
(2.94)\end{array}$ & $\begin{array}{l}.914^{\mathrm{b}} \\
(2.47)\end{array}$ \\
\hline $\begin{array}{l}\text { High Tech. Imports } \\
(H)\end{array}$ & $\begin{array}{l}.873^{\mathrm{a}} \\
(3.11)\end{array}$ & $\begin{array}{c}1.04 \\
(.955)\end{array}$ & $\begin{array}{c}.757 \\
(1.30)\end{array}$ & $\begin{array}{l}1.31^{\mathrm{a}} \\
(5.53)\end{array}$ & $\begin{array}{l}1.79^{\mathrm{a}} \\
(3.49)\end{array}$ & $\begin{array}{l}.801^{\mathrm{c}} \\
(1.91)\end{array}$ \\
\hline $\begin{array}{l}\text { Non-High Tech. } \\
\text { Imports (NH) }\end{array}$ & $\begin{array}{l}-.855^{\mathrm{a}} \\
(-3.12)\end{array}$ & $\begin{array}{l}-.949 \\
(-1.67)\end{array}$ & $\begin{array}{l}-1.07^{\mathrm{a}} \\
(-2.80)\end{array}$ & $\begin{array}{l}-1.16^{\mathrm{a}} \\
(-5.51)\end{array}$ & $\begin{array}{l}-1.48^{a} \\
(-3.34)\end{array}$ & $\begin{array}{l}-1.69^{a} \\
(-4.07)\end{array}$ \\
\hline
\end{tabular}




\begin{tabular}{|c|c|c|c|c|c|c|}
\hline & $.939^{\mathrm{a}}$ & $\begin{array}{c}.783 \\
(1.04)\end{array}$ & $\begin{array}{r}a \\
(3.47)\end{array}$ & $\begin{array}{r}{ }^{\mathrm{a}} \\
(5.30)\end{array}$ & $\begin{array}{r}\mathrm{b} \\
(2.52)\end{array}$ & $\begin{array}{r}\mathrm{a} \\
(5.18)\end{array}$ \\
\hline & $.199^{c}$ & $\begin{array}{c}.232 \\
(.471)\end{array}$ & $\begin{array}{r}b \\
(2.36)\end{array}$ & $\begin{array}{r}\mathrm{a} \\
(7.93)\end{array}$ & $\begin{array}{r}\mathrm{b} \\
(2.73)\end{array}$ & $\begin{array}{r}{ }^{\mathrm{a}} \\
(8.31)\end{array}$ \\
\hline Adjusted $\mathbf{R}^{2}$ & $\begin{array}{l}96 \\
68 \\
\end{array}$ & $\begin{array}{l}25 \\
.77 \\
14 \\
\end{array}$ & .70 & 109 & $\begin{array}{l}18 \\
.93 \\
37 \\
\end{array}$ & .77 \\
\hline
\end{tabular}

aSignificant at the $1 \%$ confidence level. $5 \%$ conf. level. c

$\mathrm{d}$

All variables are in natural logarithms. T-statistics are in parentheses.

\section{Dependent Variable: Growth of Real GDP Per Capita ( $Y$}

Eq. (3')

\begin{tabular}{|c|c|c|c|}
\hline & (1) $O L S$ & $\begin{array}{l}\text { (2) } \\
I V\end{array}$ & $\begin{array}{c}\text { Random Effects } \\
I V\end{array}$ \\
\hline & $\begin{array}{l}.014 \\
(.798)\end{array}$ & $\begin{array}{r}\mathrm{c} \\
(1.95)\end{array}$ & $\begin{array}{r}\mathrm{a} \\
(3.16)\end{array}$ \\
\hline capita $\left(Y_{t-1}\right.$ & $\begin{array}{l}-.001 \\
(-.374)\end{array}$ & $\begin{array}{r}\mathrm{c} \\
(-1.90)\end{array}$ & $\begin{array}{r}a \\
(-2.97)\end{array}$ \\
\hline Capital Stock (K) & $\begin{array}{l}.268 \\
(5.86)\end{array}$ & $\begin{array}{l}.424 \\
(3.51)\end{array}$ & $\begin{array}{l}.371 \\
(4.73)\end{array}$ \\
\hline $\begin{array}{c}\text { Growth of High Tech. } \\
\qquad \text { ) }\end{array}$ & $\begin{array}{r}\mathrm{a} \\
(12.5)\end{array}$ & $\begin{array}{r}\mathrm{b} \\
(4.07)\end{array}$ & $\begin{array}{r}\mathrm{a} \\
(3.23)\end{array}$ \\
\hline & $\begin{array}{l}-.0003 \\
(-.485)\end{array}$ & $(1.31)$ & $\begin{array}{l}.002 \\
(2.26)\end{array}$ \\
\hline Observations & .56 & 32 & $\begin{array}{l}96 \\
.52 \\
\end{array}$ \\
\hline
\end{tabular}

a

$\mathrm{b}_{5 \%} \%$ conf. level. $\quad 10 \%$ conf. level.

All variables are in natural logarithms. tatistics are in parentheses.

Hence, the positive and significant coefficient estimate for high technology imports proxying for openness.

Furthermore, since the coefficient for the real GDP level is also positive and controls for 
the scale of the economy, we know that the significance of the high technology capital goods is also not due simply to scale effects.

41

The conclusions of the Connolly (1997) growth model are strongly dependent upon the assumptions concerning the processes of imitation and innovation. Hence, it is important to empirically consider some of the basic assumptions driving the model's results. Two of the key assumptions of the Connolly (1997) model are the functional forms proposed for the processes of capital goods imitation and innovation. The probability of innovation is assumed to depend positively on the total resources devoted by firms to research, negatively on the complexity of the good upon which firms are attempting to improve, and positively on past learning to learn in domestic research whether in imitative or innovative processes. The probability of successful imitation follows a similar functional form as innovation, with the exception that the fixed cost of imitation is assumed to be a decreasing function of the real level of high technology imports from the developed country and the domestic transportation and communication infrastructure level. This specification reflects the idea that increased exposure to and familiarity with the latest capital good innovations from developed countries makes domestic imitation less costly. Similarly, better transportation and communication infrastructure levels, which include things such as roads, ports, and telephone lines, will also reduce the cost of gathering information about new innovations.

Table 2. Growth Regressions

Eq. (3') (using White's Heteroskedasticity Correction)

Dependent Variable: Growth of Real GDP Per Capita ( $Y)$

\begin{tabular}{|c|c|c|c|c|}
\hline & $\begin{array}{c}(1) \\
\text { Cross-Section } \\
\text { (Between) } \\
2 S L S\end{array}$ & $\begin{array}{c}(2) \\
\text { Random Effects } \\
2 S L S \\
(\theta=0) \Rightarrow \text { same as } \\
\text { pooled } 2 S L S\end{array}$ & $\begin{array}{c}(3) \\
\text { Cross-Section } \\
\text { (Between) } \\
2 S L S\end{array}$ & \begin{tabular}{|c}
$(4)$ \\
Random Effects \\
$2 S L S$ \\
$(\theta=0) \Rightarrow$ same as \\
pooled $2 S L S$
\end{tabular} \\
\hline Constant & $\begin{array}{l}.070 * * \\
(1.80)\end{array}$ & $\begin{array}{c}.073 * * * * \\
(2.78)\end{array}$ & $\begin{array}{c}.108 * * * * \\
(3.96)\end{array}$ & $\begin{array}{c}.106 * * * * \\
(3.49)\end{array}$ \\
\hline
\end{tabular}

${ }^{41}$ Rapp and Rozek (1990) also have an index of intellectual property right enforcement which ranges in value from 0 in countries where there are no intellectual property protection laws, to 5 where the protection and enforcement laws are "... fully consistent with the minimum standards proposed by the U.S. Chamber of Commerce." However, I have chosen to use the Park index rather than the Rapp and Rozek index for two reasons. Firstly, the Rapp and Rozek index is time invariant, whereas the Park index follows each country over five-year intervals. Secondly, I have found fewer multicollinearity problems when using the Park index rather than the Rapp and Rozek index. The more salient results of the regressions however, remain regardless of which index is used. 


\begin{tabular}{|c|c|c|c|c|}
\hline capita $(Y)$ & $.008 *$ & $\begin{array}{l}-.009 * * * \\
(-2.46)\end{array}$ & $(-3.66)$ & $-.014 * * * *$ \\
\hline $\begin{array}{l}\text { Growth of per capita } \\
\text { Capital Stock ( ) }\end{array}$ & $.367 * * * *$ & $\begin{array}{c}.297 * * * * \\
(3.55)\end{array}$ & $(2.19)$ & $.356 * * * *$ \\
\hline $\begin{array}{l}\text { Growth of per capita } \\
\text { High Tech. Imports }(H)\end{array}$ & $\begin{array}{l}.148 * * \\
(1.86)\end{array}$ & $\begin{array}{c}.096 * * * * \\
(3.79)\end{array}$ & $\begin{array}{l}.180 * * * \\
(2.54)\end{array}$ & $\begin{array}{c}.145 * * * * \\
(3.71)\end{array}$ \\
\hline Domestic Innovation $(I)$ & $\begin{array}{l}.001 \\
(.637)\end{array}$ & $\begin{array}{l}.002 * * \\
(1.79)\end{array}$ & $\begin{array}{l}.003^{*} \\
(1.53)\end{array}$ & $\begin{array}{c}.003 * * * \\
(1.97)\end{array}$ \\
\hline DC Dummy & & & $\begin{array}{c}.015 * * * * \\
(2.79)\end{array}$ & $\begin{array}{c}.016^{* * *} \\
(2.11)\end{array}$ \\
\hline $\begin{array}{l}\text { DC* Growth of per } \\
\text { capita High Tech. } \\
\text { Imports }(D C H)\end{array}$ & & & $\begin{array}{l}-.372 * * \\
(-1.92)\end{array}$ & $\begin{array}{c}-.267 * * * \\
(-2.44)\end{array}$ \\
\hline $\begin{array}{l}\text { Observations } \\
R\end{array}$ & $\begin{array}{l}33 \\
.66 \\
\end{array}$ & $\begin{array}{l}111 \\
.52 \\
\end{array}$ & $\begin{array}{l}33 \\
.73 \\
\end{array}$ & $\begin{array}{l}111 \\
.49 \\
\end{array}$ \\
\hline
\end{tabular}

$* * * *$ Significant at the $1 \%$ confidence level. $* * * 5 \%$ conf. level. $* * 10 \%$ conf. level. $* 15 \%$ conf. level. All variables are in natural logarithms. $\quad$ t-statistics are in parentheses.

\section{Imitation and Trade: Empirical Findings}

\section{Technology, Trade and Growth: Empirical Findings}

Note that there are two possible proxies for the effect of foreign technology on domestic growth. In the model, foreign technology affects domestic growth in two ways. Firstly imports of foreign capital goods are used as inputs in final goods production, thus allowing the domestic country to benefit from foreign innovations immediately. So when considering this effect of foreign technology, growth in imports of high technology goods per capita is the relevant proxy. Secondly, imports of these high technology goods have an indirect effect by reducing domestic costs of imitation, thereby potentially increasing domestic rates of technological progress either through imitation or innovation. This indirect effect may best be proxied by growth in the levels of imports of high technology goods from developed countries to reflect the fact that greater overall exposure, rather than exposure per capita, matters to costs and probabilities of imitation. Since the direct 
effect of foreign technology likely dominates, growth of per capita imports of capital goods from developed countries is used as a proxy for the effect of foreign technology on presented in the appendix and are consistent with the findings presented here. 